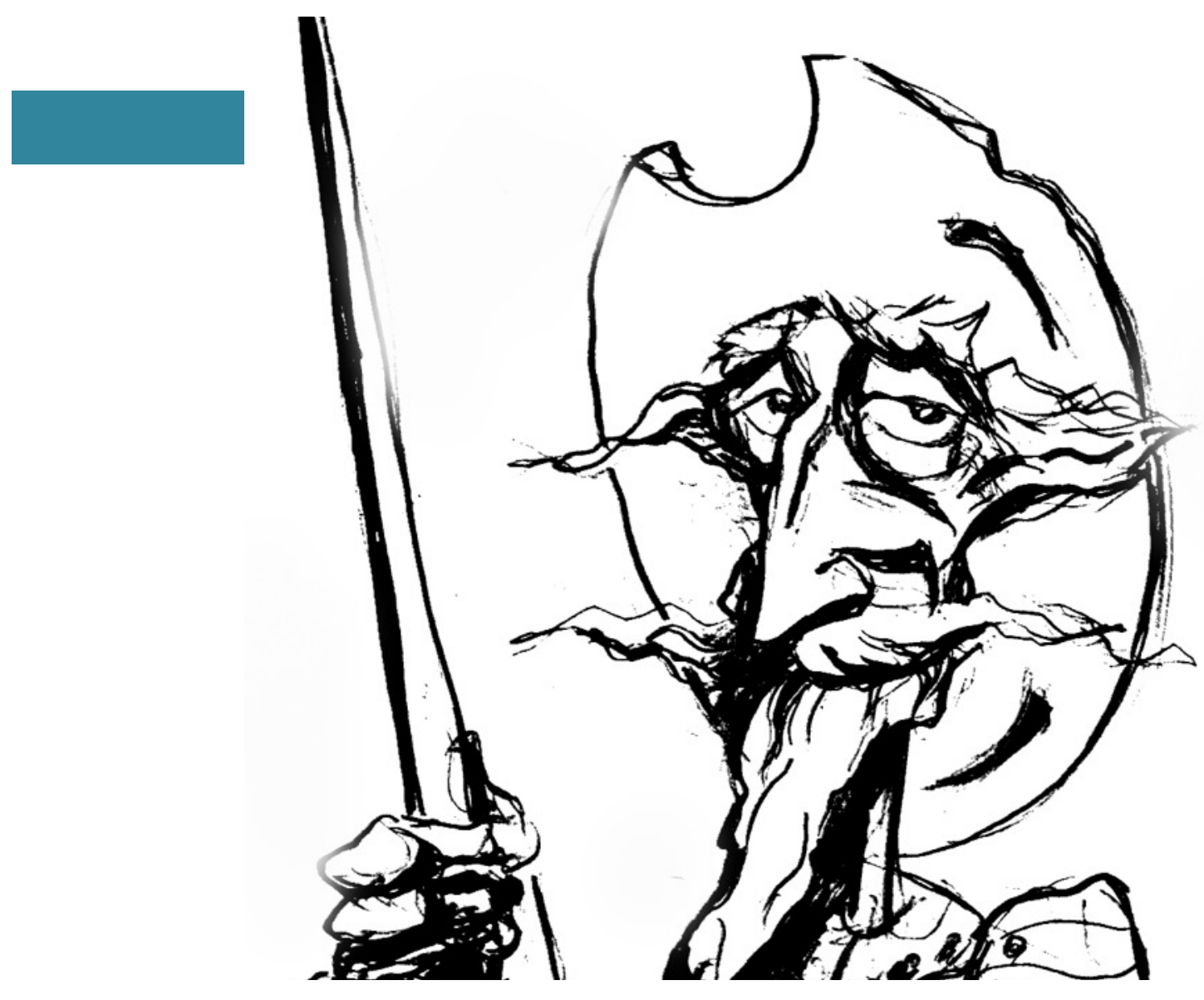

Las prácticas electorales coloniales y la conformación de un habitus electoral.

El Cabildo de la Villa de Luján entre 1771 y 1821. [Vicente Agustín Galimberti] 


\title{
Las prácticas electorales coloniales y la conformación de un habitus electoral. El Cabildo de la Villa de Luján entre 1771 y $1821^{*}$
}

\author{
The Colonial Electoral Practices and the Making of an Electoral Habitus. The \\ Cabildo de la Villa de Luján between 1771 and 1821
}

VicENTE AgUstín GALIMBERTI

\section{Resumen}

Este artículo examina los procesos electorales desarrollados durante las últimas décadas del período colonial en la jurisdicción del Cabildo de la Villa de Luján. El objetivo del mismo consiste en analizar la posible existencia de tradiciones y prácticas electorales coloniales que pudieron haber informado y orientado a los actores frente a los cambios que trajo en las elecciones la adopción del principio de la soberanía popular durante de la revolución. Analizamos la vida política local, considerando a los habitantes y los pueblos rurales como sujetos activos en la construcción tanto de una tradición electoral como en los cambios que se desarrollaron en ella durante las primeras décadas del siglo XIX.

\section{Palabras clave}

Elecciones - política local - peticiones soberanía popular - campaña de Buenos Aires

\begin{abstract}
This article examines the electoral processes developed during the last decades of the colonial period in the jurisdiction of the Cabildo de la Villa de Luján, a rural town located near Buenos Aires. The aim of this paper is to investigate the existence of a colonial electoral tradition and the practices that may have informed and guided the actors to deal with the changes brought on elections as a result of the adoption of the principle of popular sovereignty after the revolution. The text considers rural people and towns as political actors engaged in the construction of both an electoral tradition and the changes in that tradition that took place in the first decades of the nineteenth century.
\end{abstract}

\section{Key words}

Elections - local politics - petitions - popular sovereignty - Buenos Aires countryside

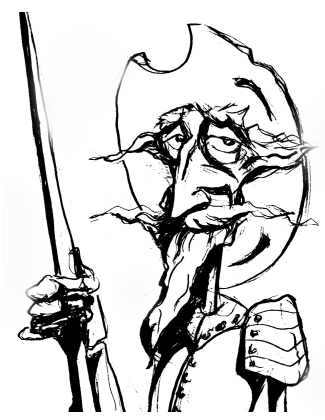

Recibido con pedido de publicación el 20 de octubre de 2017

Aceptado para su publicación el 10 de enero de 2018

Versión definitiva recibida el 22 de febrero de 2018

Vicente Agustín Galimberti, Universidad Nacional de Luján (UNLu), Argentina; e-mail: agustingalimberti@hotmail.com * Agradezco las críticas y sugerencias a versiones previas del presente escrito realizadas por Gabriela Tío Vallejo, Raúl
Fradkin, Gustavo Paz, Fabián Herrero, Marcelo Marchionni y evaluadores anónimos de Prohistoria.

Esta obra se publica bajo licencia Creative Commons. Atribución-NoComercial-CompartirIgual Internacional

Galimberti, Vicente Agustín "Las prácticas electorales coloniales y la conformación de un habitus electoral. El Cabildo de la Villa de Luján entre 1771 y 1821”, Prohistoria, Año XXI, núm. 29, jun. 2018, pp. 43-67.43 
El estudio de los procesos electorales decimonónicos en Hispanoamérica ha experimentado una gran renovación en las últimas décadas. ${ }^{1}$ Empero, producto del énfasis puesto en la novedad de las elecciones basadas en la soberanía popular, que comenzaron a desarrollarse con las revoluciones de independencia, la historiografía no ha dedicado la misma atención a analizar los procesos electorales durante el período colonial. Así, no se han profundizado las posibles experiencias, prácticas y tradiciones existentes cuando comenzaron a desarrollarse las elecciones "modernas". ${ }^{2}$

Sin embargo, distintas investigaciones, con otros intereses historiográficos, han dado cuenta de la importancia de las culturas políticas previas para afrontar los cambios y problemáticas que la revolución trajo aparejados. Entre otras, nos interesa destacar dos. Por un lado, aquellas dedicadas a analizar la vecindad como espacio desde donde se construyó la ciudadanía y, por el otro, los estudios sobre el funcionamiento de los cabildos que fueron los que asumieron la retroversión de la soberanía ante la crisis monárquica. Estas temáticas, muy relacionadas con los estudios electorales, han sido destacadas por diferentes historiadores. Sin interés de ser exhaustivos, brindaremos algunos casos para ilustrar la anterior consideración.

Por ejemplo, en el caso de Nueva Granada, Margarita Garrido mostró cómo la experiencia política previa de la población local (mayoritariamente blanca y mestiza) en los cabildos prefiguró actitudes que muestran importantes continuidades entre la colonia y la república en la política local. ${ }^{3}$ También Marco Bellingieri, en sus artículos sobre los cabildos en Yucatán, encontró que, a pesar de que las elecciones en ellos eran un mecanismo de asignación de funciones más que de delegación de la soberanía, la introducción del sufragio popular formalizó y fue funcional a las antiguas libertades estamentales, otorgando a esta tradición electoral nuevos significados e implicancias. De esta forma, a partir de las tradiciones locales coloniales, la cultura política yucateca pudo fundamentar nuevamente la legitimidad de sus antiguos cuerpos políticos, adaptándolos a las nuevas exigencias de la representación política. ${ }^{4}$ Por su

\footnotetext{
${ }^{1}$ La bibliografía sobre el tema es abundante. Por ello solo citamos algunos ejemplos, a saber: ALJOVÍN DE LOSADA, Cristóbal y NUÑEZ, Francisco "Ensayo bibliográfico: las elecciones peruanas decimonónicas", en Elecciones, núm. 6, Lima, 2006, pp. 219-241; ANNINO, Antonio (coord.) Historia de las elecciones en Iberoamérica, siglo XIX, FCE, Buenos Aires, 1995; IRUROZQUI, Marta (ed.) La mirada esquiva. Reflexiones sobre la interacción del Estado y la ciudadanía en los Andes (Bolivia, Ecuador y Perú), siglo XIX, CSIC, Madrid, 2005; MONSALVO MENDOZA, Edwin "Ciudadanía y elecciones en el mundo hispánico. Elementos para un debate historiográfico", en Historia Caribe, núm. 15, Barranquilla, 2009, pp. 158-183; SABATO, Hilda (comp.) Ciudadanía política y formación de las naciones. Perspectivas históricas de América Latina, FCE, México, 1999; y TERNAVASIO, Marcela La revolución del Voto. Politica y elecciones en Buenos Aires 1810-1852, Siglo XXI, Buenos Aires, 2002.

${ }^{2}$ En un reciente libro sobre las prácticas electivas en occidente previas a la instalación de los sistemas representativos modernos, Oliver Cristin sostiene la existencia de una "confiscación liberal de la historia del voto". La misma habría distorsionado el conocimiento histórico sobre los procesos electorales previos. CRISTIN, Oliver Vox Populi: una historia del voto antes del sufragio universal, SB, Buenos Aires, 2017, p. 8.

${ }^{3}$ GARRIDO, Margarita “La política local en Nueva Granda. 1750-1810”, en Anuario Colombiano de Historia Social y de la Cultura, núm. 16-17, Bogotá, 1988-1989, pp. 37-56.

4 BELLINGERI, Marco "Soberanía o representación: legitimidad de los cabildos y la conformación de las instituciones liberales en Yucatán" y "Del voto a las bayonetas; experiencias electorales en el Yucatán constitucional e independiente", en MONTALVO,
} 
parte, Beatriz Rojas, en la región de Zacatecas, halló que las nuevas formas de soberanía y representación, producto de la experiencia previa, no pudieron desligarse de los ayuntamientos, los cuales se vieron reforzados tanto por la situación bélica como por la aplicación de la Constitución de Cádiz. ${ }^{5}$

Considerando la totalidad del espacio novohispano y otorgando una fuerte centralidad a la Constitución gaditana, Antonio Annino indicó que la extensión de sus ayuntamientos generó una "revolución territorial" que eliminó la distinción entre cabildos de españoles y de indios igualándolos en jerarquía. ${ }^{6}$ Annino, aunque compartía con François Guerra el carácter revolucionario de las Cortes y la Constitución de Cádiz, ${ }^{7}$ advertía que la nueva ciudadanía gaditana fue readaptada por las comunidades, a partir de la noción de vecino y gracias a los ayuntamientos, según sus necesidades y condiciones, generando serios problemas de gobernabilidad al México del siglo XIX. La tesis de Annino ha sido muy discutida, principalmente en las causas del proceso de transferencia de derechos soberanos a las comunidades como en el carácter rupturista entre el orden colonial y el independiente que la misma propone. Por un lado, historiadores como Juan Ortiz Escamilla y José Serrano Ortega advirtieron que la "revolución territorial" no se produjo a través de los ayuntamientos gaditanos sino por medio de las necesidades de las comunidades locales para afrontar la situación de guerra (formar milicias y recaudar fondos, por ejemplo). Así, fueron los procesos desencadenados por las guerras de independencia las que permitieron los rápidos y profundos cambios políticos que otorgaron a las comunidades mayor autogobierno, y no la mera aplicación de la Constitución, que vino más a legalizar una situación ya dada que a imponer una nueva realidad. ${ }^{8}$ Mientras que por el otro, las investigaciones Edgar Mendoza García y Antonio Escobar Ohmstede, por ejemplo, mostraron que más que una revolución territorial surgida a partir de la Constitución, hubo una combinación de costumbres, estructuras mentales, relaciones de dominación y formas de acción propias del período colonial con las nuevas leyes liberales, siendo el gobierno local, justamente, el ámbito donde las continuidades políticas y económicas fueron más marcadas. ${ }^{9}$ En este sentido, Claudia Guarisco,

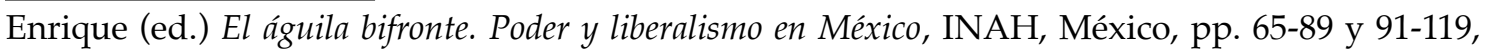
respectivamente.

${ }^{5}$ ROJAS, Beatriz "Soberanía y representación en Zacatecas: 1808-1835", en Relaciones. Estudios de historia y sociedad, XXII, núm. 85, 2001, pp. 193-221.

' ANNINO, Antonio "Cádiz y la revolución territorial de los Pueblos Mexicanos 1812-1821", ANNINO, Antonio (coor.) Historia..., cit., pp. 177-226; y "Ciudadanía "versus" gobernabilidad republicana en México. Los orígenes de un dilema", en SABATO, Hilda (comp.) Ciudadanía..., cit., pp. 62-93.

${ }^{7}$ Para el historiador francés la instalación de las Cortes de Cádiz hacia 1810 y la proclamación de la soberanía nacional que reemplazó a la Real, fue el momento fundamental en que se realizó la mutación cultural hacia la modernidad liberal, con el triunfo, en España, de nuevos términos, valores, lenguajes e imaginarios, principalmente entre las elites políticas. GUERRA, François Modernidad e Independencias. Ensayos sobre las revoluciones hispánicas, MAPFRE, Madrid, 1992.

${ }^{8}$ ORTIZ ESCAMILLA, Juan Guerra y gobierno. Los pueblos y la independencia de México, Universidad de Sevilla/Universidad Internacional de Andalucía/El Colegio de México/Instituto Mora, Sevilla, 1997; y SERRANO ORTEGA, José “La jerarquía subvertida: Ciudades y Villas en la Intendencia de Guanajuato, 1787-1820", en TERÁN, Marta y SERRANO ORTEGA, José (eds.) Las guerras de independencia en la América española, El Colegio de Michoacán, México, 2002, pp. 403-422.

${ }^{9}$ MENDOZA GARCÍA, J. Edgar “Del cabildo colonial a la municipalidad republicana: territorio y gobierno local en Oaxaca", en SALINAS SANDOVAL, María, BIRRICHAGA GARDIDA, 
realizando un balance historiográfico, sostuvo que los ayuntamientos no constituyeron una realidad totalmente nueva y sugería, para analizar el cambio cultural que significó el proceso revolucionario, considerar el pasado cultural donde el mismo se efectuó ya que el reconocimiento de lo nuevo se llevó a cabo en términos de lo viejo. Es decir, la adopción de nuevas creencias, valores y símbolos que sirvieron de referentes para la acción requirieron de la preexistencia de entidades en cierta medida afines. ${ }^{10}$

Estos estudios, sobre la vecindad y los cabildos, tanto de españoles y/o de indígenas como de mestizos y/o pardos, aunque no concentran igualmente su atención en las prácticas electorales, nos permiten poner en relieve una idea de la cual resulta la conjetura del presente escrito: cuando el proceso revolucionario habilitó nuevas instancias de participación electoral, las sociedades hispanoamericanas contaban con un conjunto de prácticas desarrolladas durante el período colonial para elegir autoridades en cabildos, cofradías y gremios, como para nombrar apoderados y diputados, que les permitieron afrontar los nuevos desafíos que la soberanía popular trajo aparejados, apelando a los criterios y modos de acción conocidos, construidos previamente. Es decir, nuestra suposición sostiene que las elecciones desarrolladas a partir de la revolución fueron condicionadas por las culturas políticas de cada zona, permitiendo combinaciones múltiples entre imaginarios y prácticas anteriores y otras más recientes. En este sentido, las prácticas electorales previas habrían orientado los comportamientos de los actores ante el desarrollo de nuevas formas electorales, permitiendo adaptarlas y resignificarlas frente a las nuevas instancias y principios políticos. Así, los desarrollos políticos americanos fueron la resultante de las tradiciones existentes, la emergencia de otras nuevas, de los condicionamientos de cada sociedad y de los usos que los actores sociales hicieron, dando lugar a configuraciones históricas originales. ${ }^{11}$

Es nuestra intención, pues, profundizar en el conocimiento de las prácticas electorales que pudieron haber informado a los actores sin partir de clasificaciones dicotómicas entre lo supuestamente "antiguo" o "moderno", sino intentando establecer la geografía y la cronología de los distintos

Diana y ESCOBAR OHMSTEDE, Antonio (coords.) Poder y gobierno local en México 1808-1857, El Colegio Mexiquense/El Colegio de Michoacán/Universidad Autónoma del Estado de México, México, 2011, pp. 375-409; y ESCOBAR OHMSTEDE, Antonio “'Ha variado el sistema gubernativo de os pueblos'. La ciudadanía gaditana y republicana fue ¿imaginaria? para los indígenas", SALINAS SANDOVAL, María, BIRRICHAGA GARDIDA, Diana y ESCOBAR OHMSTEDE, Antonio (coords.) Poder..., cit., pp. 151-191. El último autor es tajante sobre la valoración de la Constitución de Cádiz al indicar que la historiografía ha sobrevalorado un texto de corta aplicación, principalmente en su primer período (un año entre 1812 y 1814), y que fue derogada ante la restauración de Fernando VII sin mayores quejas por parte de los supuestos beneficiarios.

${ }^{10}$ GUARISCO, Claudia “La Constitución de Cádiz y la participación política popular en la Nueva España, 1808-1821. Balance y nuevas perspectivas", en Revista Complutense de Historia de América, núm. 33, 2007, pp. 55-70.

11 Ver en este sentido GARAVAGLIA, Juan Carlos "Manifestaciones iniciales de la representación en el Río de la Plata: la Revolución en la laboriosa búsqueda de la autonomía del individuo (1810-1812)", en Revista de Indias, núm. 231, Madrid, 2004, pp. 349-382; TíO VALLEJO, Gabriela Antiguo Régimen y Liberalismo. Tucumán, 1770-1830, UNT, Tucumán, 2001; y “Campanas y fusiles, una historia política de Tucumán en la primera mitad del siglo XIX", en TÍO VALLEJO, Gabriela (coord.) La república extraordinaria. Tucumán durante la primera mitad del siglo XIX, Prohistoria, Rosario, 2011, pp. 21-78. 
momentos de transformaciones que llevaron a la modernidad. ${ }^{12}$ Un conocimiento preciso de estas nos brindará mayores elementos para poder entender de forma más acabada cómo experimentaron las sociedades hispanoamericanas la sustancial modificación de su cultura política que pasó de ser preponderantemente monárquica a crecientemente republicana y que pareciera haber significado la emergencia de nuevas formas de concebir, percibir y relacionarse con el poder. Ellas permitieron, en buena medida, la conformación de una nueva ficción política basada en la soberanía popular que permitió a una minoría gobernar de forma legítima y aceptada por la mayoría. ${ }^{13}$

Nuestros intereses pueden resumirse en un interrogante: ¿Qué aspectos de las prácticas electorales coloniales permitieron afrontar las desarrolladas durante el período revolucionario e independiente? Para lograr nuestro cometido examinaremos los procesos electorales desarrollados en el Cabildo de la Villa de Luján entre 1771 y 1821 en pos de identificar sus principales características considerando los momentos y lugares de realización, las formas de participación de las autoridades y de los distintos sectores de la población rural, los mecanismos que permitieron su puesta en acción, los oficios que estaban en juego y la repercusión de los resultados. El trabajo está dividido en dos apartados cronológicos que tienen como divisoria de aguas el año de 1813 ya que fue a principios del mismo cuando se realizaron por primera vez, como tendremos oportunidad de relatar, elecciones basadas en la soberanía popular.

\section{Luján durante el siglo XVIII}

Luján era un pequeño poblado ubicado a unos 75 kilómetros de Buenos Aires en la frontera oeste de la campaña bonaerense (ver mapa 1). Su origen, como el de otros poblados de la región, se remontaba a la fundación de una capilla a fines del siglo XVII (1682). Sin embargo, a diferencia del resto, en 1755, gracias a la acción de los vecinos principales, el Rey le otorgó el título de Villa y se instaló allí un cabildo. ${ }^{14}$ Desde su establecimiento el mismo estuvo compuesto por un alcalde ordinario, un alguacil mayor, dos regidores y un mayordomo, mientras

\footnotetext{
${ }^{12}$ En este sentido seguimos a François Guerra cuando afirmaba, en uno de sus últimos trabajos y corrigiendo en parte algunas de sus hipótesis, que "...la Modernidad, antes de ser una realidad, es la conceptualización de algo que, obviamente, no existió nunca en toda su pureza en ningún lugar, ni desarrolló todas sus potencialidades inmediatamente." GUERRA, François "De la política antigua a la política moderna. Algunas proposiciones", en Anuario del IHES, núm. 18, Tandil, 2003, pp. 211-212.

${ }^{13}$ Edmund Morgan plantea que todo gobierno descansa, principalmente, en el consentimiento de la mayoría (los gobernados) hacia una minoría (los gobernantes). Este consentimiento se logra gracias a la creencia en una ficción política que, aunque tenga semejanza con los hechos (no puede apartarse mucho de ellos sin peligro a desmoronarse), se basa en la suspensión voluntaria de la incredulidad. Ejemplos de ficciones políticas serían que el rey es divino, que el gobierno es justo, que el gobierno encarna la voz del pueblo, que los representantes son el pueblo o que todos los hombres son iguales, entre otras. Así, una de las principales características de estas ficciones resulta su imposibilidad de ser demostradas empíricamente y, por lo tanto, deben sustentarse en la creencia tanto de los gobernados como de los gobernantes, otorgando legitimidad y aceptación al gobierno. MORGAN, Edmund La invención del pueblo. El surgimiento de la soberanía popular en Inglaterra y Estados Unidos, Buenos Aires, Siglo XXI, 2006.

${ }^{14}$ UDAONDO, Enrique Historia de Nuestra señora de Luján. Tomo II, Talleres Gráficos Oficiales, La Plata, 1942; GARAVAGLIA, Juan Carlos "Buenos Aires: de ciudad a provincia", en FRADKIN, Raúl (dir.) Historia de la provincia de Buenos Aires: tomo 2: de la Conquista hasta la crisis de 1820, Edhasa, Buenos Aires, 2012, pp. 33-35.
} 
que el oficio de fiel ejecutor se alternaba cada cuatro meses entre los regidores. ${ }^{15}$ En 1759 los dos regidores fueron nombrados como defensor de pobres y de menores, y a partir de 1762 se agregó un regidor decano. Así, hasta su supresión en 1821 este cabildo estuvo compuesto, pues, por un alcalde ordinario, un alguacil mayor, un regidor decano, un defensor de pobres, otro de menores y un mayordomo. ${ }^{16}$ Este último, a diferencia de los anteriores no tenía ni voz ni voto en la elección del cabildo entrante. Contextualmente, el cabildo lujanense fue parte del proceso de transformación que emprendieron los Borbones para dotar de gobierno y justicia a las poblaciones y territorios hacia mediados del siglo XVIII. ${ }^{17} \mathrm{Y}$ en comparación con otros del espacio rioplatense su composición fue más pequeña ${ }^{18}$ y no encontramos oficios vendibles. ${ }^{19}$

Su jurisdicción era muy amplia (ver mapa 1), sin embargo, era una región poco poblada. Según los padrones de 1744, el pueblo de Luján tenía 193 habitantes, mientras que en el territorio que poco más tarde recortaría su jurisdicción se encontraban 1058 habitantes. ${ }^{20}$ Para administrar justicia en esta población, designaba dos alcaldes de hermandad por año desde 1761, uno para Areco y otro para Cañada de la Cruz. El crecimiento poblacional y los pedidos de los vecinos (volveremos sobre esta cuestión) provocaron la creación de nuevas alcaldías de hermandad: para Pilar en 1793, desde 1798 para Navarro, en 1810 para la Guardia de Luján y a partir de 1812 para Fortín de Areco, totalizando seis alcaldías bajo jurisdicción del Cabildo de la Villa de Luján. A su vez, desde 1780 Luján era sede de la Comandancia de Fronteras.

La vida de este Cabildo tuvo que lidiar con la presencia a muy corta distancia del importante Cabildo de Buenos Aires como de las autoridades allí

\footnotetext{
${ }^{15}$ En 1756 Juan Lezica y Torrezuri, quien había realizado las gestiones para que Luján logre el título de Villa, fue nombrado alférez real y procurador general perpetuo, pero el título fue negado por el Consejo de Indias. ZORRAQUÍN BECÚ, Ricardo La organización política argentina en el período hispánico, Editorial Perrot, Buenos Aires, 1967, pp. 369-370.

${ }^{16}$ Por único año hubo: en 1760 un protector de naturales, en 1762 un regidor vitalicio y en 1777 un fiscal. Entre 1756 y 1771 no se especifica en todos los años cuál cabildante hacía las veces de defensor de pobres y cuál de menores. Por lo tanto en estos casos suponemos que los regidores se repetían las funciones de defensor quedando el más antiguo como regidor decano. Por el contrario, desde 1772 la fuente especifica año a año qué regidor ocupa cada oficio. En Archivo Histórico Estanislao Zevallos (en adelante AHEZ), Libro de Acuerdos del Extinguido Cabildo de la Villa de Luján (en adelante LAECVL). Por un listado de los cabildantes entre 1756 y 1821 ver UDAONDO, Enrique Historia..., cit., pp. 235-243.

${ }^{17}$ BARRIERA, Darío "Tras las huella de un territorio", en FRADKIN, Raúl (dir.) Historia de la provincia..., cit., p. 79.

${ }^{18}$ En general los cabildos rioplatenses estuvieron compuestos por dos alcaldes ordinarios, seis regidores y varios oficiales y funcionarios (procuradores, alféreces, mayordomos), en ZORRAQUÍN BECÚ, Ricardo La organización política..., cit., pp. 316 y 369.

${ }^{19}$ La única referencia sobre la compra de un oficio ocurrió hacia fines de 1793 cuando un vecino solicitó la puesta en subasta pública el oficio de alguacil mayor. Sin embargo, luego de que el mismo sea comprado por Josef Díaz Vélez por 602 pesos en marzo de 1794, este no asumió el cargo argumentando "... $q^{\text {e. }}$. en la ocasion pres ${ }^{\text {te }}$. me allo ynutil $p^{\text {a }}$. poseer semejante cargo." Hacia 1804 el fiscal de Su Majestad en lo civil y de la Real Hacienda indicaba sobre el expediente celebrado para subastar dicho oficio que el mismo estuvo "extraviado entre los pepeles del finado.. Antonio Pinedo $\mathrm{p}^{\mathrm{r}}$. espacio de mas de ocho años despues de celebrado el remate..." Ambas citas en Archivo Geneal de la Nación (en adelante AGN) IX-20-3-1, 12-05-1794 y 12-121804 , respectivamente.

${ }^{20}$ TARTAGLIA, María y TUIS, Claudio Aportes demográficos para la historia lujanense, P.A.Y.S., Luján, 1993, p. 17. La jurisdicción estipulada para el Cabildo de la Villa de Luján era desde el Río Las Conchas (actual Reconquista) en el este hasta el río Areco en el oeste, y desde el Río Paraná en el norte hasta la difusa frontera con el indio en el sur. Ver mapa 1.
} 
asentadas que buscaron controlarlo, limitar su autonomía y disputar su jurisdicción. Como se aprecia en el mapa la jurisdicción asignada al Cabildo de la Villa de Luján partía la continuidad territorial del Cabildo porteño. ${ }^{21}$

\section{Mapa 1: Jurisdicción del Cabildo de la Villa de Luján a inicios del siglo XIX ${ }^{22}$}

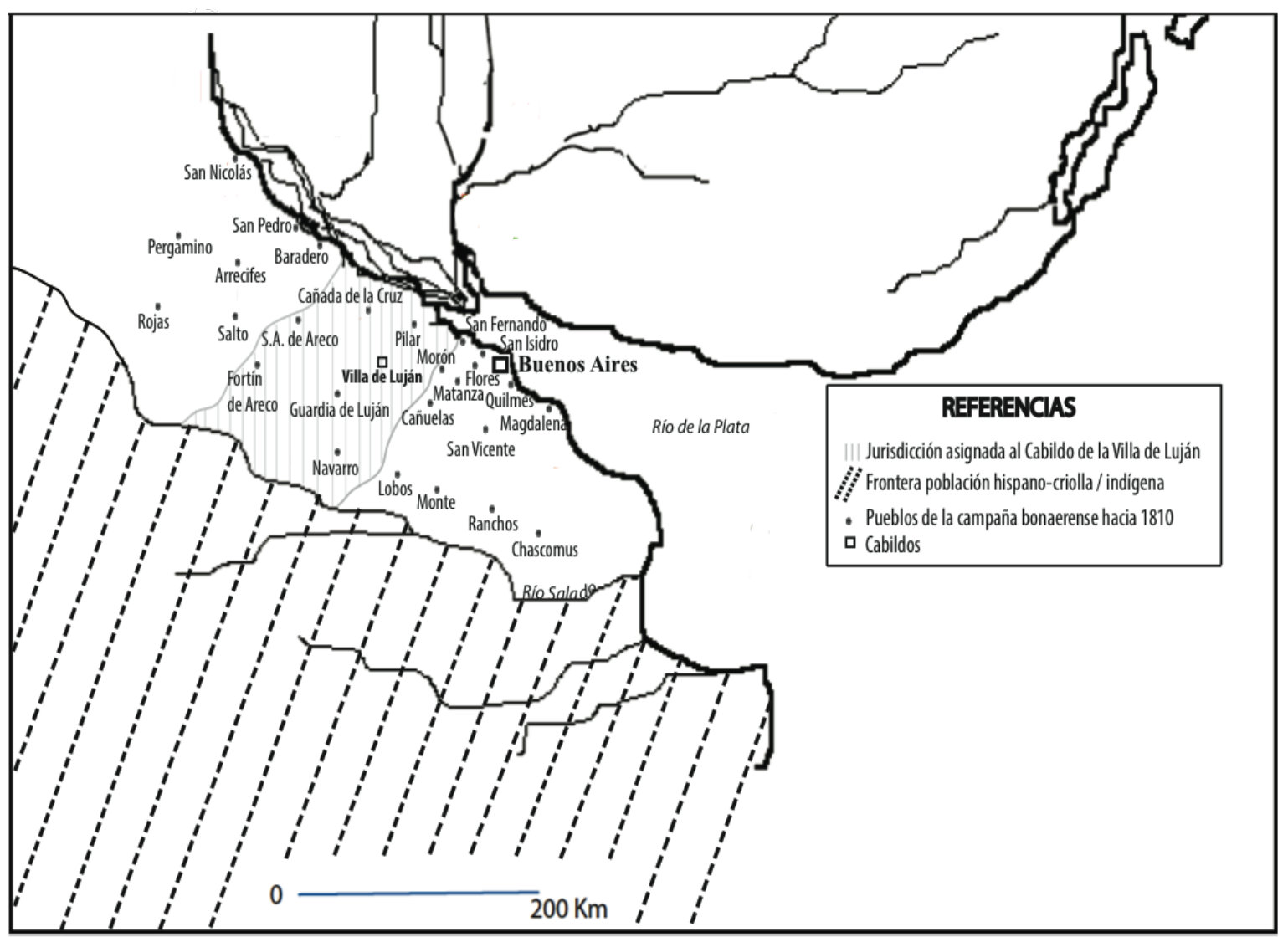

En relación a las actividades económicas, entre fines del siglo XVIII y principios del XIX, Luján contaba con una importante producción hortícola y ganadera (destacándose en la producción lechera), lo cual convertía a la región en una zona mixta según la clasificación realizada por Garavaglia. ${ }^{23}$ A su vez, Luján era un lugar de descanso y de paso para las carretas en el camino real ya sea para entrar a Buenos Aires o para viajar hacia el interior del Virreinato, a Chile o al Alto Perú. ${ }^{24}$ Esta situación favoreció el desarrollo de labores relacionadas con el transporte y la comercialización de diversos productos.

\footnotetext{
${ }^{21}$ Por las mismas el Cabildo lujanense fue suspendido entre 1783 y 1787-89, y luego intervenido entre 1812 y 1814. Por cuestiones temáticas y de espacio no hemos incluido en la presente dichos conflictos.

${ }^{22}$ El mapa tiene fines orientativos y fue construido privilegiando nuestra zona de interés. Por estos motivos no se incluyeron las dependencias de la jurisdicción del Cabildo de Buenos Aires que abarcaban la zona norte y este del Río de la Plata.

23 GARAVAGLIA, Juan Carlos Pastores y labradores de Buenos Aires. Una historia agraria de la campaña bonaerense, 1700-1830, Ediciones de la Flor/IEHS/Universidad Pablo de Olavide, Buenos Aires, 1999, pp. 137 a 143.

${ }^{24}$ MARQUIEGUI, Dedier Estancia y poder político en un partido de la campaña bonaerense (Luján, 1756-1821), Biblios, Buenos Aires, 1990, p. 13.
} 
Estas actividades permitieron un importante crecimiento económico y demográfico de la región. Según los padrones de 1813, la Villa de Luján contaba con 2.056 habitantes repartidos en 277 unidades censales de 7,4 integrantes en promedio. ${ }^{25} \mathrm{El} \mathrm{51,2 \%}$ eran hombres. Es decir, prácticamente, había la misma cantidad de hombres y de mujeres. La media etaria de la población era de 24 años, siendo los menores de 20 el 46,9\% del total y los mayores de 60, el 5,7\%. Claramente se aprecia que era una población muy joven, la cual provocó junto a las corrientes migratorias un importante crecimiento poblacional. Según el empadronador, la gran mayoría de los habitantes fue calificada como blanca (79\%) mientras que los pardos, negros e indios representaban el 9,1, 7,4 y 4,3\%, respectivamente. En relación a sus ocupaciones predominaban los labradores $(31,9 \%)$, seguidos por los peones $(27,4 \%)$, estancieros $(14,1 \%)$, criados $(12,5 \%)$, actividades comerciales $(7,1 \%)$, oficios artesanales $(5,6 \%)$ y eclesiásticos $(1 \%)$. En resumen, era una zona poblada por familias de pequeños y medianos productores rurales y algunos grandes hacendados, que dividían el uso de sus tierras en actividades agrícolas y ganaderas.

Para tener una dimensión sobre la población comprendida en la jurisdicción lujanense debemos sumar los partidos dependientes del este Cabildo. Si realizamos esta operación, la cifra asciende casi a 13.000 habitantes. ${ }^{26}$ Por lo tanto, consideramos que este espacio es un observatorio para estudiar las prácticas electorales desarrolladas por parte de la población rural que les permitieron afrontar los cambios que la revolución trajo. Finalmente, este caso es sugestivo por otro motivo. Nos permite ver la transformación en la naturaleza de los cabildos en una zona donde no se aplicó la Constitución de Cádiz como lo fueron los territorios que conformaban el Virreinato del Río de la Plata.

\section{Las elecciones en el Cabildo de la Villa de Luján entre 1771 y 1813}

Las elecciones desarrolladas en el Cabildo de la Villa de Luján entre 1771 y 1813 se componían de cuatro momentos: la calificación de votos, la elección de capitulares y designación de alcaldes de hermandad, la confirmación por las autoridades superiores y, finalmente, la jura y toma de posesión de los oficios. Por cuestiones de espacio, la descripción que realizaremos será acotada y centrada en las variables que nos parecieron sustanciales.

La calificación de votos se hacía todos los 31 de diciembre, aunque a partir de 1803 comenzó a realizarse cada 30 de noviembre por orden del virrey. ${ }^{27}$ ¿En qué consistía? Reunidos en la sala capitular, los cabildantes debían declarar que se encontraban aptos y sin impedimentos para votar al día siguiente a los sujetos que ocuparían los empleos concejiles. Esta era la oportunidad para denunciar situaciones que imposibilitaban votar a alguien. Veamos unos ejemplos. Durante la calificación del 30 de diciembre de 1772, los restantes integrantes del cabildo indicaron que el alcalde ordinario "...se abia mesclado con cuentas del Rl. erario...", por lo cual "...no debia detener bos altiba, ni

\footnotetext{
${ }^{25}$ Los datos han sido calculados a partir del padrón levantado en 1813. AGN X-7-2-4.

${ }^{26}$ Según los padrones levantados en 1813, los pueblos dependientes eran Pilar, S.A. de Areco, Cañada de la Cruz, Navarro, Guardia de Luján y Fortín de Areco, y tenían 3398, 1609, 2452, 879, 1995 y 526 habitantes respectivamente. AGN X-7-2-4.

${ }^{27}$ LAECVL, 30-11-1803. El motivo del cambio fue dar más tiempo (todo diciembre) para que los electos se enteren, acudan al Cabildo y tomen posesión de sus empleos el primero de enero.
} 
pasiva..." provocando que al día siguiente quede excluido "...segun la ley $7^{\mathrm{a}}$. livo 4. titto. $2^{\circ}$. tomo $4^{\circ}$. de las ress. de Indias..." ${ }^{28}$ Otra ocasión ocurrió en la calificación de diciembre de 1800 cuando se produjeron acusaciones cruzadas entre el alcalde y el defensor de menores por más de dos horas. Ante esto, el regidor decano mandó a que se retirasen a otra pieza para, junto al alguacil y al defensor de pobres, acordar que, ante la discordia de aquellos individuos "....que altercaron mas de dos horas, y no pudiendo convenirlos de ningun modo...", se separasen sus votos de la presente elección y "...que esta se hiciese por solo los tres que se hallavan haviles é idoneos..." ${ }^{29}$

De esta forma, la clasificación era el momento de impugnar a alguno de los electores teniendo en cuenta la normativa vigente y servía para dejar fuera de la elección a posibles disidentes. Esta situación podía generar fuertes altercados. Así, en 1775, el alcalde y el alguacil mayor votaron por Juan de la Fuente ante lo cual el regidor decano y los defensores de menores y de pobres se opusieron, luego de votar por José A. Leguizamón, argumentando que no podía aquel ser electo por "...ser pulpero y ejercer personalmte. el oficio..." Frente a la acusación, aquellos respondieron que ya habían sido alcaldes varios pulperos años anteriores poniendo mozos para atender las pulperías, e intentaron rebatir al candidato rival afirmando que era "...publica su suma pobreza." ${ }^{30}$ La respuesta argumentó que tenía un modo decente de vivir. Cuando el testimonio fue enviado al gobernador y capitán general, este confirmó las elecciones por la persona que había obtenido más votos e indicó “...qe. en adelante se abstenga de igual procedimto. pr. qe. sobre ser contra ordenanza es tambien un medio qe. puede producir disenciones... -y-...cuiden en lo subsesivo la observancia de las ordenanzas pa. las demas elecciones qe. se ofrescan." ${ }^{31}$ Es decir, era el día de la clasificación y no de la elección el momento de las impugnaciones. ${ }^{32}$

Luego de la calificación, se debían proponer a las personas que podían ocupar el cargo de alcalde para el año entrante. En la mayoría de los $39 \operatorname{casos}^{33}$ que consultamos se presentó una terna ( 25 veces). En el resto de las situaciones se seleccionó un sujeto (6 casos), dos (5), cuatro (2) y en una oportunidad siete

\footnotetext{
${ }^{28}$ LAECVL 30-12-1772 y 01-01-1773

${ }^{29}$ LAECVL 31-12-1800

${ }^{30}$ LAECVL 01-01-1775. Las Leyes de Indias en su Libro $4^{\circ}$, Título X "De los oficios consejiles", Ley XII indicaban "Que los regidores no contraten, ni sean regatones, ni tengan tiendas por si, ni por otros, ni usen oficios viles.", pero como vemos parece que en Luján esto no se cumplió, aunque pudo servir como argumento para impugnar a un rival. "Leyes de Indias", en Archivo Digital de la Legislación en el Perú, disponible en

${ }^{31}$ LAECVL 13-01-1775

http: / / www.congreso.gob.pe/ntley/LeyIndiaP.htm

32 Según Dedier Marquiegui este conflicto muestra ciertas reticencias dentro del grupo de familias tradicionales para incorporar al cuerpo capitular a aquellas que se habían enriquecido con las actividades comerciales como bien detallan las citas arriba expuestas. MARQUIEGUI, Dedier Estancia..., cit., p. 33 a 35. Sin embargo, estas trabas no parecen ser tan firmes. Por ejemplo, Juan de la Fuente, resistido en esta elección de 1775, logra ser electo como regidor decano para el Cabildo de 1777 y de 1779, mientras que ya lo había sido en 1771 .

${ }^{33}$ No se realizaron las de los años entre 1782 y 1786 por un conflicto jurisdiccional con el Cabildo de Buenos Aires. Cuando fue nuevamente habilitado el Cabildo lujanense el 16-04-1787 se realizó la calificación de votos que inició la elección del nuevo Cabildo para dicho año. El 31 de diciembre se volvió a hacer la calificación para nombrar al Cabildo entrante. Por este motivo, en 1787 hubo dos calificaciones. LAECVL
} 
posibles alcaldes. Los candidatos debían según la ley residir en la jurisdicción del Cabildo. ${ }^{34}$

El segundo momento era la elección del nuevo cabildo y la designación de los alcaldes de hermandad por parte de los regidores salientes. La elección, que se hacía el primer día del año y desde 1803 el primero de diciembre, consistía en que cada uno de los cabildantes/electores debía dar su voto a viva voz para cada oficio. En el cuadro 1 resumimos la información encontrada para intentar responder al siguiente interrogante: ¿Qué competencia existió en estas elecciones? Como vemos, la mayoría fueron unánimes o canónicas. Sin embargo, es posible apreciar una diferencia entre los distintos tipos de oficios. Así, mientras que los defensores ${ }^{35}$ generaron pocos problemas, la vara de alcalde provocó mayores desacuerdos. Esta función, la más importante dentro del cabildo, generó disidencias en 17 de las 39 elecciones analizadas. Como vemos en el cuadro 1, existieron varias elecciones en las cuales el fallo de los electores se encontró dividido. Al ser cinco los cabildantes, en las votaciones disputadas el reparto de los votos fue de cuatro contra uno o de tres contra dos, salvo en dos de ellas donde estuvieron presentes solo cuatro regidores y el resultado fue un empate en dos.

Cuadro 1: Elecciones unánimes y disputadas según oficio entre 1772 y 1814

\begin{tabular}{|l|l|l|l|}
\hline Oficio & Unánimes & Disputadas & Total \\
\hline Alcalde & 22 & 17 & 39 \\
\hline Alguacil & 25 & 14 & 39 \\
\hline Regidor decano & 26 & 13 & 39 \\
\hline Defensor de menores & 27 & 12 & 39 \\
\hline Defensor de pobres & 29 & 10 & 39 \\
\hline \multicolumn{2}{|r|}{ Fuente: Elaboración propia a partir de LAECVL }
\end{tabular}

De esta forma, las elecciones en este cabildo se muestran como mayoritariamente unánimes, aunque no totalmente. En este sentido es interesante marcar que, a pesar de la mayoría de elecciones unánimes en cada oficio, en solo 13 de las 39 ocasiones la totalidad del cabildo entrante fue nombrado de este modo. Es decir, en varios años existió una disputa por los oficios que no pudo ser consensuada por los cabildantes en ejercicio. En ciertos contextos el entredicho se expresó en un conflicto abierto. Los siguientes

\footnotetext{
${ }^{34}$ Libro $4^{\circ}$, Título X “De los oficios consejiles", Ley $7^{\circ}$ en “Leyes de Indias", cit.

${ }^{35}$ Una posible explicación de esta mayor presencia de elecciones unánimes en los defensores puede deberse a que estos oficios eran pocos requeridos y los nombrados solían excusarse para no ocuparlo. Al haber poco interés de los vecinos en el puesto, hubo menor "ejercicio de influencias" y competencia en la elección capitular. Igualmente es una hipótesis que requeriría verificación. Agradezco a Gabriela Tío Vallejo por advertirme sobre esta cuestión.
} 
ejemplos nos permitirán apreciar algunas prácticas electorales desarrolladas en aquellos tiempos.

En 1774 se produjo un empate en los cinco oficios capitulares y en las dos alcaldías de hermandad, ya que los electores fueron cuatro por no estar presente el regidor decano. El enfrentamiento fue liderado por el alcalde y el alguacil por un lado, y los dos regidores restantes por el otro. Esta situación solía ser bastante común en los cabildos cuando el grupo desplazado un año disputaba con el nuevo que controlaba la institución. Igualmente, lo interesante del caso es que en la decisión no parecen haber influido solo los cabildantes sino que también participaron varios vecinos de la Villa y su jurisdicción. ¿Cómo lo hicieron? Estos “...pressentaron al Sor. Thente. de rey. y Govor. Into. pr. un Memorial Infamatorio contra nosotros pa. conseguir el qe. no los confirmaran..." 36 Estas operaciones nos muestran otros modos de acción de los vecinos que intentaban influir en las autoridades superiores para resolver las disputas locales en su favor. Posiblemente, la situación de empate entre los capitulares provocó la necesidad de movilizar por fuera del propio ayuntamiento fuerzas para definir el conflicto, ampliando la participación más allá de los propios cabildantes. En este caso, el gobernador decidió confirmar como nuevo alcalde al candidato de los acusados, mientras que completó los oficios con los votados por los otros, recompensando de alguna forma a cada sector. $^{37}$

Pasemos a otro ejemplo: hacia 1794, luego de la elección como alcalde fue confirmado por el virrey Juan Irrazabal quien solo obtuvo un voto y fue acusado por el cabildo de "...inhavilp ${ }^{a}$. egercerdh ${ }^{\circ}$. cargo..." al estar sumariado por "...ser uno de los partidarios opuestos á las determinazs. de este cuerpo..." Ante la decisión de confirmar a Irrazabal, el cabildo pidió al virrey, mediante una representación, que revocara su decisión y confirmara como alcalde a Gaspar Contreras, quien había ganado la elección con dos votos, aclarando que en caso de que "...no accediese a tan justa súplica, $\mathrm{q}^{\mathrm{e}}$. se le pidiese el permiso $\mathrm{p}^{\mathrm{a}}$. interponer el correspon ${ }^{\text {te }}$. recurso ante el Tribunal de la $\mathrm{R}^{1}$. Aud ${ }^{\mathrm{a}}$." Entre otros cargos, se acusó a Irrazabal de

“...conspiraciones fomentadas en casa de Dn. Domingo Maqueda... $\mathrm{p}^{\mathrm{a}}$. perpetuar la jurisdicción Ordinaria qe. egercia en deposito de la vara el Regdor. de Cano $\mathrm{D}^{\mathrm{n}}$. Gaspar Contreras, induciendo a los hombres rudos é ignorantes $\mathrm{p}^{\mathrm{a}}$. $\mathrm{q}^{\mathrm{e}}$. no le ovedeciesen, y proponiendose otros ultrages y bejamenes al citado $\mathrm{D}^{\mathrm{n}}$. Gaspar... -de esta forma, hombres- ...escudados del patrocinio de Irrazabal subscitaron unas ruidosas novedades persiguiendo a quantos han sido sus opuestos levantando parcialidades $\mathrm{y}$ entrando el vecindario en disturvios $\mathrm{y}$ desazones de la may. ${ }^{\mathrm{r}}$ consecuencia." 38

Sean ciertas o no las denuncias, este tipo de acusaciones nos llevan al centro de la disputa electoral. El problema consistía en la gobernabilidad de la jurisdicción. Es decir, quién iba a mandar y qué sector se iba a beneficiar de ello. Mientras el virrey decidía, el control del cabildo lo tenía el grupo de Contreras quien se posesionó del oficio de alcalde como interino. Sin embargo, la otra

\footnotetext{
${ }^{36}$ LAECVL 01-02-1774

${ }^{37}$ LAECVL 01-01-1774 y 23-01-1774

${ }^{38}$ LAECVL 17-01-1794
} 
parcialidad, apoyada por algunos vecinos, puso su autoridad en entredicho con distintas maniobras. Entre ellas, ampliando el espectro social de los apoyos (los hombres rudos e ignorantes) para generar desobediencias a la autoridad en el pueblo. Estas acciones tuvieron efecto ya que, meses después, Contreras se presentó al Cabildo e informó su situación diciendo

“...q. el deposito berificado en mi no fuese tan opuesto a el dictamen de los $\mathrm{q}^{\mathrm{e}}$. en la actualidad inquietan esta republica $\mathrm{p}^{\mathrm{r}}$. cuyo motivo se esperimentan tan notables tropelías desovediencias e insultos en aquellos... -y agregaba- ...esta maquina de oposicion de mis emulos rueda sobre la Justificada perfidia de no ser gobernados por mi... $\mathrm{p}^{\mathrm{r}}$. lo $\mathrm{q}^{\mathrm{e}}$. atendiendo a tan fatales consequencias tan opuestas no solo a la sociedad republicana sino al sublimado y real caracter de la Justicia..." 39

Finalmente, recién en julio, el virrey declaró nula la elección y ordenó que se deposite la vara en el regidor decano. ${ }^{40}$ Nuevamente, nos encontramos con acciones que sin ser propiamente electorales y sin ser realizadas por aquellos que eran electores/cabildantes, terminaban por influir en las elecciones y sus resultados. Más adelante volveremos a reflexionar sobre las mismas. Ahora, continuemos con nuestra descripción.

Luego de elegido el nuevo cabildo, se designaban los alcaldes de hermandad para los partidos dependientes. Como ya dijimos, estos eran dos desde 1761, 3 desde 1793, 4 desde 1798, 5 desde 1810 y 6 desde 1812. Además, en diferentes oportunidades el cabildo designó varios jueces comisionados, ${ }^{41}$ los cuales eran nombrados con la "comisión" de una tarea específica que en la mayoría de los casos estuvo relacionada con la gran extensión del territorio a cubrir por los alcaldes y la necesidad de perseguir "...toda clace de ladrones, matadores, hombres cargados de delitos y gentes vagas $\mathrm{q}^{\mathrm{e}}$. a el se refugian con el seguro de estar el Alcalde de la Herm ${ }^{d}$. distante muchas leguas..." ${ }^{22}$ Así, se comisionaba al juez para que recorriera la jurisdicción y "...ponga freno a tanto desorden..." ${ }^{43}$

Hasta 1800 los alcaldes de hermandad fueron votados por los cabildantes salientes como el resto de los oficios para, luego, ser confirmados por la autoridad superior. Mientras que desde 1801 se propuso una terna para que el virrey nombrase al que consideraba conveniente. ¿Cómo eran seleccionados los mismos? Veamos un ejemplo. El 7 de marzo de 1809, llegó la respuesta del alcalde de Cañada de la Cruz a un oficio del cabildo donde le pedía que propusiera individuos de idoneidad para el empleo. ${ }^{44}$ Así, parece ser que la terna era propuesta por el alcalde que concluía su período. Esto nos lleva a pensar sobre la existencia de acciones por parte de ciertos vecinos de los lugares subordinados para influir en la designación del alcalde. Esta presunción se

\footnotetext{
${ }^{39}$ LAECVL 22-03-1794

${ }^{40}$ LAECVL 08-07-1794

${ }^{41}$ Se nombraron en los siguientes años: en 1773 uno para el Pago de la Choza y otro para Cañada de la Cruz, en 1804 para Navarro, en 1809 para Fortín de Areco, en 1811 uno por cada partido que había al momento en la jurisdicción, en 1812 dos para Navarro y dos para la Guardia de Luján, 1813 uno a tres leguas de la Villa y otro para Cañada de Escobar.

${ }^{42}$ LAECVL 14-08-1804

${ }^{43}$ LAECVL 11-05-1773 o similar en 24 y 26-05-1809

${ }^{44}$ LAECVL 07-03-1809
} 
refuerza cuando vemos los motivos por los cuales fueron nombrados jueces comisionados o creados nuevos alcaldes de hermandad. Era común que antes de nombrarse un juez o crearse una alcaldía, llegase una petición al Cabildo, remitida por los "...Hacendados labradores y bibanderos establecidos..." desde un pago por hallarse "...careciendo de que la Jurisdiccion politica", en la cual relataban las necesidades que tenían, para luego pedir un

\begin{abstract}
“...Juez $\mathrm{q}^{\mathrm{e}}$. administre Just $\mathrm{a}^{\mathrm{a}}$. en aquellos destinos donde... es mui copioso el num ${ }^{\circ}$. de jentes, y establecimientos, labrantias, y crias de ganados, tambien experimentan continuos rovos excesos y otros perjuicios... $\mathrm{p}^{\mathrm{r}}$. falta de tener inmediato un juez $\mathrm{R}^{1} . \mathrm{q}^{\mathrm{e}}$. sele y castigue dichos crimenes, administre Just ${ }^{\mathrm{a}}$. y haga guardar el orden necesario entre aquellas jentes..."45
\end{abstract}

Así, el pedido de crear una nueva alcaldía surgía de problemas específicos que indicaban los peticionantes: la falta de una justicia aplicada por un oficial con la legitimidad real que evite que "...balidos de la gran distancia para el recurro...-la misma sea ejercida- por propia mano..." Cuestión que ocasionaba que el resarcimiento de los daños origine "...rejertas funestas amas de otros males qe. diariamte. se estan advirtiendo suceder en el expresado distrito de chacras de Lujan afuera..." ${ }^{46}$ De esta manera, algunos vecinos, que posiblemente eran aquellos que veían como peligraban sus bienes, peticionaban para lograr una jurisdicción política, una autoridad que demarque el horizonte de posibilidades existentes en la vida cotidiana del lugar y sancione a quienes lo transgredieran. Es decir, la subdivisión administrativa provenía y era impulsada, en algunos casos como este, por los pobladores de los pagos y no era una mera imposición de las autoridades situadas en Buenos Aires para controlar las zonas rurales. ${ }^{47}$

En otras oportunidades encontramos vecinos que, luego de nombrado un alcalde, se presentaron ante el virrey para exhibir sus protestas. En 1803, el Cabildo propuso a un solo individuo para el cargo de Navarro “...por la falta

\footnotetext{
${ }^{45}$ Tomamos como ejemplo el caso de la Guardia de Luján en LAECVL 01-12-1809. Ver también el acta del 22-08-1812 donde los vecinos de Fortín de Areco piden un Alcalde por motivos similares.

${ }^{46}$ LAECVL 01-12-1809

${ }^{47}$ La misma situación han encontrado Antonio Galarza con la conformación del Partido de Chascomús en la jurisdicción del Cabildo de Buenos Aires y Darío Barriera con el Partido de Coronda en el espacio del Cabildo de Santa Fe, donde los vecinos pedían a sus respectivos cabildos de la creación de alcaldías, luego de exigir en otras oportunidades el nombramiento de jueces comisionados para "administrar justicia" dada la insuficiencia de alcaldes de hermandad en relación a la enorme dimensión del territorio. Ver BARRIERA, Darío "El gobierno de los campos entre el reformismo borbónico y la política de los vecinos: partidos, districtos y jueces delegados", en BARRIERA, Darío y FRADKIN, Raúl (eds.) Gobierno, justicias y milicias: La frontera entre Buenos Aires y Santa Fe (1720-1830), La Plata, Universidad Nacional de La Plata, 2014, p. 119; GALARZA, Antonio “¿Quiénes son las autoridades? Un análisis socioeconómico de las autoridades locales en un partido del sur de la campaña de Buenos Aires. Chascomús entre 1808 y 1821", en Anuario del Instituto de Historia Argentina, núm. 12, Universidad Nacional de la Plata, 2012, p. 90. Barriera avanza sobre la cuestión e indica que la designación de jueces como la creación de nuevos distritos no respondió a la aplicación de ningún capítulo de la Real Ordenanza de Intendentes. Por el contrario, esta dejó el espacio abierto a los cabildos y vecinos para que desarrollen sus propios modos de organizar el gobierno de los campos. De esta forma, el impulso para desarrollar los mismos no proviene desde "arriba" (intendentes, gobernadores o virreyes que luego si tuvieron mayor celo en la designación de las personas para ocupar esos cargos) sino del pedido de los vecinos.
} 
que hay en este partido de hombres que sepan leer y escribir..." Frente a esto, un vecino de la zona, por medio de una representación al virrey, manifestó que aquel era

“...un sujeto enteram ${ }^{\text {te }}$. idiota e ignorante que carece del todo de la facultad de leer y escribir... -ya que- firman otros a su ruego. A mas de esto es un hombre pobrisimo y a quien tengo acusado en autos que SE paso al Trib ${ }^{1}$. de la $R^{1}$. Aud ${ }^{a}$. y se hallan aun pendientes de haberme substraido algunos ganados de mi hacienda, de modo que el origen de la reeleccion no es otro que el querer authorizar con este empleo para que me haga mas daño y me cause mas extorciones que las que me ha hecho, como ha sido entre otras la escandalosa de haberme impedido el recojo de mis gandados a rodeo con las resultas de haber dado de palos a mi hijo $\mathrm{D}^{\mathrm{n}}$. Juan Pedro sin mas causa..." 48

A esto agregaba que había otros vecinos que sabían leer y escribir, a quienes, luego de describirlos elogiosamente, proponía y rogaba que alguno de ellos sea nombrado como alcalde. Por su parte, el Cabildo de Luján defendió la elección realizada y criticó el escrito del vecino, aduciendo que su estancia era una madriguera de salteadores y que solo "...intenta destruir la buena fama..." del alcalde. ${ }^{49}$ Finalmente, la Real Audiencia confirmó la elección hecha por el cabildo, desestimando las quejas del vecino. ${ }^{50}$

Como en las representaciones pidiendo un juez comisionado, la creación de una alcaldía o la elección de un determinado alcalde ordinario, en este caso vemos los intentos de algunos vecinos de influir en las designaciones de alcaldes de hermandad sea proponiendo individuos o intentando impugnar a otros. En las mismas estaban en juego aspectos importantes de la vida cotidiana de los pobladores rurales como el acceso a las tierras y los ganados, la posibilidad de sancionar a quienes acometían contra estos bienes y el establecimiento de un orden de cosas previsible. Es decir, estaba en juego la gobernabilidad de estos territorios de reciente colonización. Para lograrla, pareciera que la aceptación por parte de las personas que debían ser "gobernadas" resultaba elemental ya que de ellas dependía la capacidad de ejercer justicia que tenía el alcalde de hermandad.

Al carecer de importantes medios coercitivos para conseguir sus fines, la negociación y el consenso adquirían mayor relevancia. En este sentido resulta reveladora la forma en que un alcalde comentaba su primer contacto con el vecindario sobre el cual tenía que ejercer justicia. Él afirmaba, hacia 1795, que "...trató hacerse reconocer por aquellos vecinos publicando su nombram ${ }^{\text {to }} . .$. ."51 ante la gente que asistió a la misa mayor. Una situación similar exponía el síndico procurador de Buenos Aires cuando en una carta al virrey explicaba sobre el nombramiento del alcalde de Pilar “...que en el primer dia festivo estandose dando a reconocer (este es el estilo que se usa en el campo) despues de la misa mayor, y leyendo su nombramiento en concurso de una multitud de Gente." ${ }^{22}$ Aún más explícito fue Paulino Ibarra cuando informó al Cabildo de

\footnotetext{
${ }^{48}$ Archivo Histórico de la Provincia de Buenos Aires (en adelante AHPBA) 13-1-3, 12-12-1803.

${ }^{49}$ AHPBA, 13-1-3, 15-12-1803

${ }^{50}$ AHPBA, 13-1-3, 23-03-1804

${ }^{51}$ AHPBA, 13-1-3, 12-12-1795

${ }^{52}$ AHPBA, 13-1-3, 14-01-1795
} 
Luján que había cumplido la comisión de poner en posesión al nuevo alcalde de hermandad de Pilar Isidro Figuerdo diciendo:

"...lo he verificado con la solemnidad $\mathrm{q}^{\mathrm{e}}$. es debida en la mañana del dia de ayer haciendolo notorio á todo aquel Becindariop ${ }^{r}$. medio del correp ${ }^{\text {te }}$. bando $q^{\mathrm{e}}$. al efecto hise publicar fixando copias de el en los parajes mas publicos sin $\mathrm{q}^{\mathrm{e}}$. hubiese notado la menor nobedad a si en el $S^{\text {or }} \mathrm{Al}^{\mathrm{ce}}$. $\mathrm{D}^{\mathrm{n}}$. Narciso Gomes como en los Besinos moradores de aquel Pueblo..." 53

¿Qué hubiese sucedido de haber "novedad"? Seguramente, en caso de mantenerse la negativa del vecindario ante el nuevo alcalde, se hubiesen realizado acciones para cambiarlo o poner en discusión sus tareas.

Estos ejemplos como los que vimos antes sobre las elecciones de capitulares nos muestran la existencia de prácticas no propiamente electorales mediante las cuales algunos vecinos buscaban influir en la elección y/o modificar los individuos que estaban o estarían a cargo del poder local en los distintos pagos. Entre ellas la principal parece ser la escritura de representaciones. ¿En qué consistían? Su redacción era una práctica común durante la época colonial destinada a expresar y resolver conflictos entre vasallos, ciudades o cuerpos, acudiendo a una autoridad mayor, siendo el Rey la última instancia posible. Se basaba en el derecho de petición, se manifestaba en formas y contextos disímiles, y se ejercía mediante la redacción de escritos llamados súplicas, memoriales, protestas, peticiones o representaciones que se dirigían a alguna de las autoridades de la jerarquía institucional. Este derecho podía ser ejercido por los vecinos de una ciudad, pueblo o por algunas de las corporaciones existentes. ${ }^{54}$ Las mismas, en los casos comentados, parecen funcionar como un mecanismo que, sin ser electoral, permitió, según la circunstancia, impugnar o modificar una elección, lograr la designación de un juez y/o influir en la designación de una determinada persona para un cargo. A su vez, lograban ampliar la participación en las decisiones sobre las autoridades locales a otros vecinos más allá del restringido grupo que controlaba el cabildo en cada momento. Así, permitía negociaciones entre este, los vecinos y el resto de los pobladores.

Este tipo de prácticas llegó a ser utilizada por los vecinos para pedir la intervención del propio Cabildo hacia 1812 por "...desunidades -que hay- entre los mismos Individuos $\mathrm{q}^{\mathrm{e}}$. componen este Ayuntamiento $-\mathrm{y}$ entre este $\mathrm{y}-\mathrm{los}$ Vecinos de esta Villa y su Jurisdiccion." En este caso, los vecinos que se presentaron ante el Superior Gobierno lograron la intervención a pesar del reclamo del propio cabildo en donde se impugnaba el mismo diciendo que el “...informe de algunos vecinos de este Pueblo figurando desunidades que no hay ni entre los mismos Individuos qe. componen este Ayuntamiento, ni entre este con los Vecinos de esta Villa y su Jurisdiccion pues jamas podra probarse un solo caso sobre el particular..." ${ }^{55}$ Es decir, estas prácticas eran usadas

\footnotetext{
${ }^{53}$ AHEZ, Documento Antiguos Villa de Luján (en adelante DAVL), N 16 31-12-1821

${ }^{54}$ GARAVAGLIA, Juan Carlos "Manifestaciones..., cit., p. 353; GUERRA, François "De la política...", cit.; LEMPÉRIÈRE, Annick "La representación política en el Imperio Español a finales del Antiguo Régimen", en BELLINGERI, Marco (coord) Dinámicas de Antiguo Régimen y orden constitucional. Representación, justicia y administración en Iberoamérica. Siglos XVIII-XIX, Otto Editore, Torino, 2000, p. 58-59; y TÍO VALLEJO, Gabriela Antiguo..., cit., pp. 174-177.

${ }^{55}$ LAECVL 17-11-1812
} 
recurrentemente, tenían éxito en muchos casos y permitían a algunos vecinos defenderse / atacar a las autoridades o a otros sectores de la vecindad opuestos a sus intereses, negociando activamente la construcción cotidiana del poder local. ${ }^{56}$ Podemos suponer, que aquellos que tuviesen, entre otras variables, mejores conexiones e influencias sobre el árbitro (gobernador, real audiencia, virrey, superior gobierno ejecutivo según el momento), lograron sus finalidades. Volveremos sobre estas prácticas en el siguiente apartado. Ahora continuemos con la descripción de las elecciones coloniales.

El tercer momento electoral consistía en la aprobación o no de la elección por parte de la autoridad superior. Hasta la creación del Virreinato del Río de la Plata fue el gobernador de Buenos Aires el encargado de la confirmación. Luego fue el virrey y desde la revolución el Superior Gobierno de las Provincias Unidas. Este momento era crucial y mostraba el carácter dependiente ${ }^{57}$ que tenía este cabildo lujanense con respecto a las autoridades superiores, las cuales cuidaban de limitar la autonomía que en ciertos momentos aquel parecía intentar ampliar. Así, en distintas oportunidades fueron retiradas personas electas y nombradas otras, o directamente fueron anuladas las elecciones obligando a reiterarlas. ${ }^{58}$ En algunos casos esto generó que el cabildo intente defender sus decisiones. Para ello, acudía a alguna autoridad superior mediante el nombramiento de un diputado, apoderado o representante, a quien los cabildantes le daban “...todo nuestro poder lleno, compluido y bastante, qual por dro. se requiere y es necesario, para mas valer. ...para que representando nuestras Propias Personas, como si presentes fuesemos..." 59 De esta forma, el representante o diputado era la persona a quien se le otorgaba, mediante un mandato imperativo, instrucciones y poderes para ejecutar una determinada acción en nombre y con la autoridad del cuerpo, en este caso, del propio cabildo. En caso de que su accionar abordase materias no estipuladas en las instrucciones, debía consultar a sus comitentes. De esta forma, el enviado no era una encarnación simbólica del grupo, sino algo más parecido a un embajador. ${ }^{60}$ En los casos que encontramos, se usó esta práctica para realizar una gestión específica, ${ }^{61}$ presentarse ante la Real Audiencia para defender sus derechos del cabildo, ${ }^{62}$ protestar frente a la intervención ${ }^{63}$ o para resolver algún conflicto entre autoridades. ${ }^{64}$

\footnotetext{
${ }^{56}$ GARRIDO, Margarita "La política...", cit., pp. 39-40; y JOSEPH, Gilbert y NUGENT, Daniel (ed.) Aspectos cotidianos de la formación del estado. La revolución y la negociación del mando en el México moderno, Era, México, 2002.

${ }^{57}$ Ver nota 21.

${ }^{58}$ LAECVL 07-01-1773, 26-10-1782, 17-01-1794, 01-01-1801, y 23-12-1812 por ejemplo.

${ }^{59}$ LAECVL 25-01-1790, otro ejemplo en 03-08-1789

${ }^{60}$ CHIARAMONTE, José “Vieja y nueva representación: los procesos electorales en Buenos Aires, 1810-1820", en ANNINO, Antonio (coord.) Historia..., cit., p. 36; GARAVAGLIA, Juan Carlos “Manifestaciones...", cit., pp. 352-54; y GUERRA, François “De la política...", cit., pp. 206 y 207.

${ }^{61}$ Por ejemplo, en 1772 se nombró un Diputado para conseguir los utensilios necesarios para construir la Sala de Acuerdos y el Calabozo del Cabildo. En 1778 para rendir obediencia frente al nuevo Virrey Vertiz. En 1789 para felicitar al nuevo Virrey Arreondo. LAECVL27-02-1772, 0407-1778 y 28-11-1789, respectivamente.

${ }^{62}$ Así sucedió en relación al conflicto jurisdiccional con el Cabildo de Buenos Aires. LAECVL 17-03-1789, 25-01-1790, 11-08-1794 y 05-11-1812

${ }^{63}$ LAECVL 17-11-1812 cuando fue intervenido el Cabildo.

${ }^{64}$ Como sucedió en 1792 entre el Comandante de Frontera y el Alcalde en la Guardia de Luján. LAECVL 28-04-1792
} 
Finalmente, el cuarto y último momento de estas elecciones correspondía a la jura de los electos y la toma de posesión de sus oficios. Para ello debían acercarse al cabildo donde las autoridades salientes les tomaban juramento de usar fiel y lealmente el oficio. Este trámite no trajo ningún tipo de inconveniente, salvo algunas demoras.

\section{Las elecciones entre 1813 y $1821^{65}$}

Para este período no podemos realizar un análisis similar al anterior debido a que las actas del Cabildo de la Villa de Luján entre 1814 y 1821 se encuentran extraviadas. Sin embargo, gracias al uso de otras fuentes primarias como a la mayor dedicación que la historiografía le ha otorgado a las elecciones de este período, ${ }^{66}$ podremos, mediante la reconstrucción de algunos procesos electorales, concentrarnos en apreciar ciertos aspectos de las prácticas comentadas anteriormente que influyeron en las desarrolladas durante la revolución.

Es una obviedad que el proceso revolucionario trajo importantes modificaciones en las elecciones que describimos en el apartado precedente. La más importante de ellas provenía del sustancial cambio de la ficción política ${ }^{67}$ que justificaba y legitimaba la autoridad, ahora basada en la soberanía popular. Esta modificación llegó a Luján pocos días después del establecimiento en Buenos Aires de la Junta Provisional Gubernativa, cuando la misma envió al cabildo un pliego donde afirmaba que "...no pudiendose ya sostenerse la unidad constitucional, sino $\mathrm{p}^{\mathrm{r}}$. medio de una Representancion $\mathrm{q}^{\mathrm{e}}$., concentre los Pueblos $p^{r}$. medio de Representantes elegidos $p^{r}$. ellos mismos... $p^{a}$. proverlegitim $^{\text {te }}$. una Autoridad $\mathrm{q}^{\mathrm{e}}$. exersa la Represenacion del $\mathrm{S}^{\text {or }}$. Don Fernando VII...", ${ }^{68}$ e invitaba a que se nombre un diputado. Esta fue la primera experiencia relacionada con la idea del origen popular del poder político que tuvo nuestra zona de interés. Sin embargo, quedó trunca ya que a los pocos días la Junta ordenó la suspensión de la elección en las villas que no eran cabeceras, ubicando al cabildo lujanense, otra vez, en una posición inferior al resto. ${ }^{69}$ Situación que evidencia las dificultades y reticencias de las elites urbanas para incluir a las vecindades rurales en el nuevo cuerpo electoral.

Recién en 1813, con motivo de la elección de diputados para integrar la Asamblea General, esta jurisdicción experimentó un proceso electoral basado en la soberanía popular. Veamos cómo se desarrolló. En este, por medio de los alcaldes de hermandad se citó a los “...asendados y Besinos $\mathrm{p}^{\mathrm{a}}$. $\mathrm{q}^{\mathrm{e}}$. ellos

\footnotetext{
${ }_{65}$ La jurisdicción del Cabildo de Luján participó entre estas fechas en las elecciones correspondientes a: A-Asambleas o Congresos en 1813, 1815, 1817, 1818 y 1819; B-Cabildo en 1815, 1816, 1817, 1818, 1819 y 1820; y C-Sala de Representantes en 1820 y 1821 en dos oportunidades por año.

${ }^{66}$ CHIARAMONTE, José “Vieja y...", cit.; GALIMBERTI, Vicente "La unanimidad en debate. Los procesos electorales en la campaña de Buenos Aires entre 1815 y 1828", en Boletín del Instituto de Historia Argentina y Americana "Dr. Emilio Ravignani", $3^{\circ}$ serie, núm. 37, Buenos Aires, 2012, pp. 88-114; GARAVAGLIA, Juan Carlos "Elecciones y luchas políticas en los pueblos de la campaña de Buenos Aires: San Antonio de Areco (1813-1844)", en Boletín del Instituto de Historia Argentina y Americana "Dr. Emilio Ravignani", $3^{\circ}$ serie, núm. 27, Buenos Aires, 2005, pp. 49-73; y TERNAVASIO, Marcela La revolución..., cit.

${ }^{67}$ Por el concepto de ficción política ver cita 13.

${ }^{68}$ LAECVL 09-06-1810

${ }^{69}$ LAECVL 23-06-1810
} 
practiquen el nombram ${ }^{\text {to }}$. de Electores $q^{\text {e }}$. han de concurrir a la Villa de Lujan a berificar el de Diputado."70 La jurisdicción del Cabildo fue dividida en ocho "cuarteles", dos por la Villa de Luján y uno por cada partido dependiente. ${ }^{71}$ Lamentablemente, no contamos con información sobre el desarrollo de las elecciones en ellos ni sobre cuántos vecinos participaron. Sin embargo, si tomamos en cuenta que las mismas se hicieron bajo el Reglamento de 1812 y este proponía que debían ser citados "...todos los vecinos libres y patriotas..." para nombrar, en forma pública y en voz alta, un elector a pluralidad de votos, ${ }^{72}$ podemos concluir que existió, en comparación con las elecciones previas, una importante ampliación del cuerpo electoral.

A la diferencia en el tamaño del cuerpo electoral en comparación con las elecciones previas a 1813, hay que agregarle un cambio de naturaleza en el proceso electoral. Mientras en las anteriores se realizaba una elección corporativa, desde 1813 se pretendía una elección representativa de ciudadanos. Sin embargo, su aplicación muestra interesantes contradicciones. Al reunirse los electores, los mismos totalizaron 13 y no 8 como había estipulado la convocatoria electora. ¿Por qué? Porque a los 8 nombrados por los vecinos (2 por la Villa de Luján y 6 por los partidos dependientes) se sumaron los 5 cabildantes del momento. Los 13 votaron uno a uno a quien consideraron más apto para diputado, al igual que se hacía en las elecciones capitulares. El ganador obtuvo la totalidad de los votos evidenciando un claro consenso previo. Así, el acto electoral muestra un cambio importante en su naturaleza al incorporar representantes votados por los vecinos de los 6 partidos de la jurisdicción del cabildo, llevando la lógica representativa al nivel de cada poblado. Sin embargo, este carácter representativo buscó ser compensado por el cuerpo capitular dado que sus 5 cabildantes también participaron, sin previa elección "popular", del nombramiento del diputado, provocando una forma representativa mixta al contener "lo viejo" (la representación corporativa capitular) como "lo nuevo" (la representación del cuerpo electoral conformado por los vecinos libres y patriotas). De esta forma, la elección muestra las contradicciones de la aplicación del principio representativo en una institución corporativa.

Una situación similar advertimos en el momento en que consagraron el nombramiento del diputado. Luego de votar al cura Francisco Argerich, los electores comenzaron a redactar el "Otorgam ${ }^{\text {to }}$. de poderes y facultades al $S^{\text {or }}$. Diputado electo $\mathrm{p}^{\mathrm{a}}$. la Augusta Asamblea $\mathrm{G}^{\mathrm{ral} . " 73}$ Es decir, el diputado fue pensado como un apoderado del cabildo, similar a los que vimos en el período previo, es decir, con mandato imperativo y no como un representante del cuerpo ciudadano conformado por todos los vecinos libres y patriotas. ${ }^{74}$

Dos años después, en 1815, entró en vigencia el Estatuto Provisional el cual ordenaba que varias autoridades, entre ellas los cabildos, debían ser

\footnotetext{
${ }^{70}$ LAECVL 25-12-1812

${ }^{71}$ LAECVL 13-01-1813

72 CANTER, Juan "La Asamblea General Constituyente”, en LEVENE, Ricardo Historia de la Nación Argentina, Vol. VI, $1^{\circ}$ sección, El Ateneo, Buenos Aires, 1947, p. 52.

${ }^{73}$ LAECVL 15-01-1813. Los poderes que le otorgan son bastante amplios e incluyen la redacción de una constitución, la imposición de contribuciones y la proclamación de la independencia.

${ }^{74}$ Sin embargo, la Asamblea aprobó que los diputados eran de las Provincias Unidas, es decir, de la "...nación en general, sin perder por esto la denominación del pueblo á que deben su nombramiento..." CANTER, Juan "La Asamblea...", cit., p. 78.
} 
nombradas por elección popular para brindarles mayor legitimidad. ${ }^{75}$ Esta normativa era más precisa sobre los habilitados a votar ya que indicaba que "Todo hombre libre, siempre que haya nacido y resida en el territorio del Estado, es Ciudadano; pero no entrará al ejercicio de este derecho, hasta que haya cumplido 25 años, o sea emancipado."76 Para realizar la elección, los alcaldes de hermandad debían convocar a sus vecinos/ciudadanos para que eligieran a los electores que nombrarían al nuevo cabildo. ${ }^{77}$ Con esta normativa se intentaba modificar la naturaleza del cabildo de manera similar a lo experimentado en los territorios donde se implementó la Constitución de Cádiz, dando lugar a los ayuntamientos electivos. ${ }^{78}$

En Luján, la elección se desarrolló los días 28 y 29 de noviembre, mientras que el 30 se reunieron los electores para nombrar a los cabildantes que se posesionarían de sus oficios el $1^{\circ}$ de enero. Como vemos, se mantuvieron las fechas en las que se realizaban las elecciones. Sin embargo, desaparecía la "calificación" que era reemplazada por la elección de los vecinos. Lo interesante de este proceso electoral es que causó una importante controversia ya que a los pocos días, por medio de una representación a la Junta de Observación, "Los vecinos de la Villa de Luxan..." pidieron, y consiguieron, su anulación por haberse quebrantado el Estatuto. ${ }^{79}$ La investigación llevada a cabo nos permite acercarnos a las prácticas que emplearon los actores para hacer frente al enorme reto que traía la novedad de la soberanía popular: por un lado, implicaba la inclusión de buena parte de los vecinos en las elecciones, mientras que por el otro, provocaba la definitiva transformación de la naturaleza del cuerpo capitular al volverlo representativo.

¿Cómo reaccionaron las autoridades locales frente a estos desafíos? Las fuentes nos dan algunas pistas. Por ejemplo, indican que “...el Alcalde recivia en la calle los votos...", mientras que el alguacil mayor se acercó a la hacienda de un vecino

“...á notificarle de orden del Alcalde compadeciese a sufragar $\mathrm{p}^{\mathrm{a}}$. los electores... con cuyo motivo le preguntó a dho Aguacil por quienes podia votar, y le contestó lo hiciese por el alcalde sigue el nombre de 4 individuos- $\mathrm{q}^{\mathrm{e}}$. eran los $\mathrm{q}^{\mathrm{e}}$. estaban previstos... y pareciendole bien... el mismo Aguacil escribió el sufragio qe. devia dar, y lo condujo á manos del Alcalde..."

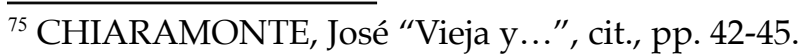

76 "Estatuto provisional para dirección y administración del Estado, Junta de observación. 5 de mayo de 1815", en Estatutos, Reglamentos y Constituciones Argentinas, Librería Platero, Buenos Aires, 1972, pp. 31-57.

${ }^{77}$ AGN IX-19-6-8, 30-11-1815

78 ANNINO, Antonio "Cádiz y...", cit.; GUARISCO, Claudia “La Constitución...”, cit.; y PERALTA RUIZ, Víctor "El impacto de las Cortes de Cádiz en el Perú. Un balance historiográfico", en Revista de Indias, LXVIII, núm. 242, 2008, pp. 67-96. Recordemos que en el Río de la Plata no se aplicó la Constitución gaditana por ser territorio rebelde a la Regencia.

${ }^{79}$ Hemos analizado en detalle esta elección en otra oportunidad. Ver GALIMBERTI, Vicente "¿'Aquí no se viene a hablar ni disputar'? Un conflicto electoral en el Cabildo de la Villa de Luján hacia 1815”, en XIII Jornadas Interescuelas/Departamentos de Historia, Catamarca, 2011.
} 
A su vez, en el momento de realizarse el escrutinio concurrieron varios vecinos, pero el cura dijo "...en altas é inteligibles voces $\mathrm{q}^{\mathrm{e}}$. aquella eleccion era secreta y que no debia saberse el nombre de los sufragantes, y que no era preciso expresar en las cedulas los nombres de los que prestaban sus sufragios y que cobraba la expresión Doy mis votos a favor de N.N." Cuando un vecino intentó hacerle ver al alcalde y al cura de la "...arbitrariedad con que se habia procedido en la Eleccion Electoral dixo el segdo. aquí no se viene á hablar ni disputar." 80

Entonces, en estas elecciones populares de cabildantes vemos el uso de mecanismos similares a los empleados anteriormente, aunque en un contexto distinto. En este, la ampliación social y territorial de los participantes en la elección aparece como el rasgo novedoso que intenta ser "controlado" y/o "inoculado" mediante prácticas que se asemejan a las usadas previamente. No sabemos cuánta gente votó en la elección anulada, pero sí conocemos que cuando se volvió a realizar votaron 135 personas. ${ }^{81}$ Esto implicaría que emitieron su sufragio el $28 \%$ de los habilitados, lo cual nos parece una proporción considerable que abarcaría a más de la cuarta parte del cuerpo electoral potencial. ${ }^{82}$

Así, el dilema que se planteó para las autoridades locales podría ser enunciado de la siguiente forma ¿Cómo hacer que al nuevo cabildo lo sigan eligiendo los cabildantes salientes de forma "secreta" y no otros sectores ajenos al mismo como un acto público? Frente a este, las autoridades del momento, junto a otros vecinos y el cura notificaron a la población sobre la elección y los sujetos "que estaban previstos para electores" para luego recolectar votos en la calle y en las casas de los vecinos. Es decir, más que en una elección, los mecanismos empleados nos remiten a una petición o representación, en la cual quienes la organizaban iban recolectando las firmas y convenciendo a quienes querían suscribirla. La expresión "doy mis votos a favor de N.N." que aparece en la descripción sugiere la misma idea. Esta fórmula consistía en que quien no podía acudir a votar/firmar la representación, informaba su voluntad a otra persona que firmaba a su ruego. También podía suceder que alguien con liderazgo firmaba en nombre de los individuos bajo su influencia, generalmente analfabetos. Así, una sola persona podía llegar a firmar por varios. Estas prácticas que combinan formas de votar individuales con otras colectivas, ${ }^{83}$ propias de la "política antigua", son las que orientaron el accionar de este grupo. Y pareciera que así fueron pensadas las elecciones por las mismas autoridades centrales como se aprecia cuando leemos que, días antes de las elecciones para oficios concejiles de 1820 para los Cabildos de Buenos Aires y Luján, la recién creada Sala de Representantes indicaba que se debía hacer la

\footnotetext{
${ }^{80}$ AGN X-8-4-5, 02-12-1815

${ }^{81}$ AGN X-8-4-5, 08-12-1815

${ }^{82}$ Según el padrón de 1813 la Villa de Luján contaba con 2056 habitantes, de los cuales 1053 eran hombres y de estos, 471 eran mayores de 25 años, es decir habilitados a votar. 135 conforma el $28 \%$ de 471, el padrón potencial. La gran cantidad de votantes no parece ser excepcional. Por ejemplo, sabemos que en Luján votaron en 1816: 101 personas, en 1817: 165 (incluye Lobos) y en 1821: 151. AGN X-21-10-7, X-8-10-3, y AHEZ, DAVL, No 87, respectivamente.

${ }^{83}$ Similares mecanismos para elecciones de la misma época en otros lugares del Virreinato del Río de la Plata encuentra GARAVAGLIA, Juan Carlos "Manifestaciones...", pp. 358-60.
} 
“...colectación de sufragios de los Ciudadanos... -y para ello pedía que se formen- ...mas comisiones colectoras..." ${ }^{84}$

Entones, sugerimos que los actores buscaron adaptar la forma de elección, por un lado a sus prácticas conocidas, y por el otro a sus intereses. Si antes un pequeño grupo, cabildantes y allegados, realizaba un "debate" y nombraba al futuro cabildo; luego de la aplicación del Estatuto que implementaba elecciones basadas en la soberanía popular, este mismo reducido grupo intentó arreglar quiénes tenían que ser los electores, para luego hacer la recolección de votos que provocase que el nombramiento fuese formalmente acorde con las nuevas disposiciones, pero sin modificar la esencia del mecanismo anterior. Es decir, un intento de adecuarlas (de forma un tanto ilegal como luego fue denunciado) para que el nombramiento del cabildo entrante siga dependiendo de las autoridades salientes, es decir, de la corporación. Así, se intentó invertir el espíritu del funcionamiento de la elección basada en la soberanía popular y en la representación. Con estas prácticas los votantes no elegirían a los electores, sino que tan solo darían sus votos por personajes previamente seleccionados por las autoridades, aprobando y legitimando el artilugio. Lo anterior, fue puesto de manifiesto por el cura cuando, frente a las quejas de los vecinos denunciantes, afirmó "aquí no se viene a hablar ni disputar", ya que hablar y disputar no correspondía a ese momento del proceso ni a un conjunto tan amplio de personas. Frente a esto, otro grupo de poder de la Villa reaccionó. ¿Cómo? Realizando una representación a una autoridad superior, la Junta de Observación, para que resuelva la controversia a su favor. Otra vez, una práctica conocida usada en un contexto diferente.

Este altercado pone de manifiesto lo problemático que resultó remozar una institución como el cabildo, propia del antiguo régimen, y vehiculizar por medio de elecciones populares la nueva ficción política, la cual ya no permitía hacer política como se practicaba antes, como una negociación en el seno de un reducido grupo de personas. Por el contrario, ahora el juego político se abría al público. Entonces, las disputas que existían entre las autoridades y grupos de poder locales pasaron a escenificarse en las calles del pueblo y permitieron la participación de un mayor número de personas. Estos cambios significaron un importante desafío para el liderazgo de unos, pero también una oportunidad para el de otros. Quienes redactaron la representación conformaban un grupo, más vinculado al comercio (tratantes y pulperos), de reciente instalación en la Villa, liderado por Salvador Aguirre, que se oponía a quienes controlaban hasta el momento el cabildo, encabezados por el alcalde Gerónimo Colman, de mayor arraigo en el lugar y vinculados con las actividades ganaderas. ${ }^{85} \mathrm{El}$ conflicto electoral analizado conforma un jalón más de una disputa por el poder local, expresada en el control del cabildo y las milicias, que venía de antes y que seguirá oscilando durante los años venideros. Por ejemplo, Aguirre se convertirá en alcalde ordinario por tres años consecutivos entre 1818 y 1820, mientras que Colman será el primer juez de paz de la Villa en 1822, luego de abolido los cabildos bonaerenses.

\footnotetext{
$\overline{{ }^{84} \text { AGN X-3-9-10, 07-12-1820 }}$

85 Para un análisis de las luchas entre los vecinos de Luján ver MARQUIEGUI, Dedier Estancia..., cit.; y TARANTO, Roxana Construir y disputar el poder. Red familiar y conflictos politicos en la Villa de Luján 1780-1820, Tesis de Licenciatura, Universidad Nacional de Luján, 2013.
} 
Lo interesante de la situación es que en esta competencia los actores usaron los mecanismos construidos previamente en un contexto nuevo. Entre ellos, la redacción de representaciones resultó de gran utilidad. Lamentablemente, por cuestiones de espacio, no podemos describir con detalle las evidencias encontradas de lo común que fueron estas prácticas que, sin ser propiamente electorales, tenían una gran influencia en las elecciones y designaciones de las autoridades. Sin embargo, indicaremos brevemente algunos ejemplos que muestran lo asiduo de su uso. Hacia 1819, en la jura a la Constitución en Capilla del Señor, se produjeron desacuerdos entre el cura y el alcalde, quienes fueron atacados y/o defendidos por representaciones de los vecinos. ${ }^{86}$ En 1820 los vecinos de Cañada de a Cruz realizaron una presentación para que el alcalde -que acusaba a aquellos de "fascinados y reboltosos" por realizar una asonada que "...va en contra del nuevo orden que pretende instaurar esta administración, es opuesto al sistema liberal, un asonada" - cese en sus funciones y se deposite el empleo en la persona que ellos proponían. ${ }^{87}$ En otras oportunidades, los vecinos por medio de representaciones pedían la destitución del cura. ${ }^{88}$ En algunos casos estos intentos fueron denunciados señalando que provenían de una "...junta tumultuosa", frente a lo cual, el atacado se defendió argumentando que no “...se había reunido en su casa una junta de esas características, sino una junta quieta -para pedir- la restitución del cura del pueblo." ${ }^{89}$ Este tipo de acciones nos llevan a una característica central del sistema electoral que se construyó en el período revolucionario y que tendría gran influencia sobre la organización electoral del Estado de Buenos Aires luego de 1820. Mientras que los electores para cabildantes o diputados como los futuros integrantes de la Sala de Representantes eran escogidos por medio de elecciones basadas en el "voto popular", las autoridades locales (jueces, comandantes y curas) eran nombradas por el poder central sin mediar mecanismos electorales. En este contexto, las representaciones funcionaron como un mecanismo que sin ser electoral permitía a los vecinos influir en las designaciones de autoridades que tenían una gran relevancia en la vida local. ${ }^{90}$ Este mecanismo tenía una larga trayectoria y había permitido negociaciones ante las designaciones de autoridades por parte de la población durante la época colonial y fue reactualizado en un nuevo contexto al finalizar la misma.

\footnotetext{
${ }^{86}$ AHEZ, DAVL N 3 y 4, 29-09-1819 y 27-09-1819, respectivamente.

${ }^{87}$ AHEZ, DAVL N ${ }^{\circ} 7,18-05-1820$

${ }^{88}$ AHEZ, DAVL N 10 y 13, 27-05-1820 y 12-06-1820, respectivamente.

${ }^{89}$ AHEZ, DAVL N ${ }^{\circ} 17,22-12-1821$

${ }^{90}$ Resulta interesante resaltar que en otras regiones del Imperio Español Americano y con otra composición social se ha encontrado situaciones similares. Claudia Guarisco explica que en los cabildos indígenas del siglo XVIII, las autoridades eran elegidas por el cabilido cesante. Sin embargo, los comunes de cada pueblo les hacían llegar sus propias propuestas mediante distinto tipos de escritos.

Guarisco, Claudia "Cabildos indígenas, democracia y autonomía. Lima, 1770-1812", en Investigaciones Sociales. Revista del Instituto de Investigaciones Histórico Sociales, núm. 12, Lima, 2004, pp. 122-124. Por su parte, Margarita Garrido en Nueva Granada encuentra que los vecinos de las poblaciones rurales, mayoritariamente blanca y mestiza, proponían alcaldes o, en otras ocasiones, objetaban los nombramientos por medio de representaciones o dando instrucciones a un apoderado para que se presente ante la Real Audiencia. Mediante las mismas, además de canalizar de forma pacífica los malestares locales, los vecinos lograban reconocerse a sí mismos como parte integral de la comunidad y del juego político. GARRIDO, Margarita "La política...", cit., pp. 39-42, 51 y 54 .
} 
De esta forma, en torno a las prácticas electorales y aquellas otras que sin ser propiamente electorales influían en las primeras, se definieron buena parte de las relaciones políticas entre la población de los partidos rurales y las autoridades, encargadas, entre otras cuestiones, de realizar las elecciones y la movilización electoral. Así, elecciones y representaciones parecen ser las dos caras de una misma moneda, a pesar de ser, el elegir y el peticionar, derechos de distinto origen y naturaleza. Si por un lado las elecciones permitían la elección de cabildantes, diputados y/o representantes que hacían real la soberanía popular sostenida en la ampliación de la base de sustentación del poder al incluir a gran parte de la población; las representaciones permitían a los vecinos/ciudadanos proponer, influir, convalidar, remover y/o cuestionar las elecciones realizadas por el poder central de las autoridades que venían a gobernarlos. En este contexto debemos interpretar la preocupación de las autoridades cuando llegaban a un pueblo donde ejercerían funciones $\mathrm{e}$ informaban que anunciaron su nombramiento "...en los pasajes más públicos del vecindario...sin haberse observado reacciones negativas." 91 O el énfasis puesto luego de la reelección del nuevo alcalde de Luján por el cura cuando notificaba que "Se concluyó el acto cantando Hymnos á la Patria con Musicas y descargas...después de un rato de satifacion y confianza en medio de vivas y aclamaciones nos dirigimos todos á casa del Sor. Alcalde felicitandole y a sus compañeros de sus nuevos cargos." 92

Así, la práctica de redactar peticiones parece funcionar como un límite al poder de las autoridades locales que traspasasen aquello que la población local consideraba posible, aceptado y correcto. Mediante ellas, apoyando a un personaje o protestando contra los elegidos o contra sus abusos cuando estaban en funciones, los paisanos bonaerenses participaron del juego político cotidiano en cuestiones que eran relevantes en su vida diaria como era el accionar de los alcaldes, jueces, curas y comandantes. Por lo tanto, participaron activamente de la construcción cotidiana del poder. ${ }^{93}$ Así, cuando un conflicto se expresaba mediante métodos violentos (una asonada, una cencerrada o un tumulto contra alguna autoridad), ${ }^{94}$ no era un suceso aislado, sino que era la evidencia de una tupida trama de negociaciones cotidianas del poder y la autoridad local que generalmente se expresaba por mecanismos más pacíficos.

Por último, resulta relevante indicar que estas prácticas también fueron utilizadas para intentar redefinir las relaciones entre los pueblos rurales con el poder central. Por ejemplo, por medio de un memorial presentado al Cabildo de Buenos Aires, los "Pueblos Libres de la Campaña", liderados por el Cabildo de lujanense pidieron durante 1820 que no se considere la cantidad de diputados al congreso por el número de habitantes sino por cada cuerpo moral, ampliando su representación. ${ }^{95}$ A su vez, un petitorio firmado por 160 "...vecinos Hacendados y Labradores de la Villa de Luján..." ${ }^{96}$ solicitando la disolución de

\footnotetext{
${ }^{91}$ AHEZ, DAVL No 16, 31-12-1821

${ }^{92}$ AGN X-11-3-3, 02-01-1820

${ }^{93}$ JOSEPH, Gilbert y NUGENT, Daniel (ed.) Aspectos..., cit.

${ }^{94}$ Fradkin, Raúl La historia de una montonera: bandolerismo y caudillismo en Buenos Aires, 1826, Siglo XXI, Buenos Aires, 2006, pp. 46, 47, 170 y 171.

95 CHIARAMONTE, José Ciudades, Provincias, Estados: Orígenes de la Nación Argentina (18001846), Emecé Buenos Aires, 2007, pp. 425-433.

96 PICCIRILLI, Ricardo Rivadavia y su tiempo, Tomo II, Peuser, Buenos Aires, 1942, p. 598-599.
} 
su cabildo terminó por provocar a fines de 1821 la desaparición de los mismos en el recién conformado Estado de Buenos Aires. ${ }^{97}$

\section{¿Un habitus electoral?}

A lo largo de este trabajo intentamos mostrar algunos aspectos de las prácticas electorales coloniales que permitieron afrontar aquellas desarrolladas durante el período revolucionario e independiente ¿Cómo explicar las influencias que describimos de las primeras sobre las últimas sin caer en la dicotomía entre lo antiguo y lo moderno, transitada muchas veces por la historiografía? ${ }^{98}$ Una opción consiste en pensar la existencia de un habitus electoral construido durante el período colonial que fue puesto en tensión durante la revolución. ${ }^{99}$

Pierre Bourdieu define habitus como los sistemas de disposiciones duraderas y transferibles incorporadas por los agentes a lo largo de sus trayectorias que generan maneras interiorizadas a actuar, percibir, valorar y pensar de cierta manera más que de otra. En él se contienen tanto la objetivación de condiciones de las experiencias pasadas como un capital, es decir, una serie de principios y estrategias posibles a partir de las cuales el agente define su acción frente a las nuevas situaciones que se presentan, según las imágenes que tiene de las mismas y en pos de conservar o aumentar su patrimonio y posición social, mediante la maximización del beneficio, sea este material o simbólico. De esta manera, el habitus constituye una serie recursos que si, por un lado, limitan las posibles acciones de los actores, por el otro, les permiten un grado de invención frente a los cambios en las condiciones en que el mismo fue generado. ${ }^{100}$

Consideramos que este concepto resulta útil para entender las prácticas electorales descriptas. A medida que se fueron realizando las restringidas elecciones coloniales, las autoridades locales y algunos vecinos rurales fueron desarrollando un habitus electoral como parte de su experiencia histórica. Entre los principales componentes y prácticas del mismo encontramos: la conformación de un consenso negociado entre los electores para nombrar nuevas autoridades que, sin embargo, no impedía la existencia de disputas por los oficios en determinadas ocasiones; la terna como forma de proponer candidatos; el uso de la figura del apoderado o diputado con mandato imperativo; la recolección de firmas/votos; el uso de peticiones para influir y/o modificar las elecciones y las personas designadas; acudir a una autoridad superior como mecanismo de arbitraje y equilibrio; la supervivencia de la

\footnotetext{
97 TERNAVASIO, Marcela "La supresión del cabildo de Buenos Aires: Crónica de una muerte anunciada?", en Boletín del Instituto de Historia Argentina y Americana "Dr. Emilio Ravignani" $3^{\circ}$ serie, núm. 21, Buenos Aires, 2000, p. 66.

${ }^{98}$ PERALTA RUIZ, Víctor "El impacto...", cit.

${ }^{99}$ Dado que el centro de nuestra atención fue encontrar los principales componentes y prácticas que informaron y permitieron a la población en cuestión afrontar los desafíos que la soberanía popular y la representación moderna trajeron, analizamos las mismas como un conjunto que en nuestra redacción aparece cristalizado, fijo y sin una cronología propia. Evidentemente estos componentes y prácticas, en tanto productos históricos, deben ser periodizados con categorías más precisas que "colonial", "revolucionario" e "independiente". Agradezco esta apropiada sugerencia, que no se puede resolver en el presente escrito, al evaluador anónimo de la revista.

100 BOURDIEU, Pierre El sentido práctico, Siglo XXI, Buenos Aires, 2007; GUTIÉRREZ, Alicia Pierre Bourdieu: las prácticas sociales, CEAL, Buenos Aires, 1994.
} 
vecindad como categoría política para definir al elector; y el uso de los alcaldes y curas como agentes intermedios para la realización de las elecciones. ${ }^{101}$

Estos componentes y prácticas, aunque con diferencias según la región, basadas en concepciones territoriales y corporativas de la organización social, fueron muy comunes a la cultura política hispana. ${ }^{102}$ Los mismos, no solo permitieron a los vecinos rurales participar indirectamente de las elecciones capitulares durante la colonia, sino que posibilitaron un abanico de opciones cuando, producto de la revolución comenzaron a desarrollarse un nuevo tipo de elecciones que traía una enorme novedad: la soberanía proviene del pueblo pero este no la ejerce sino que a través de sus representantes. Estas opciones disponibles parecen haber sido utilizadas tanto por las poblaciones donde se aplicó la Constitución de Cádiz como en las zonas insurgentes donde el texto constitucional no fue adoptado como la que acabamos de analizar. Es decir, como muestra nuestro caso, parte de la población rural había desarrollado mecanismos de participación política en las elecciones del cabildo y en la designación de los alcaldes de hermandad y jueces comisionados que les permitieron afrontar los nuevos desafíos en materia electoral logrando, por un lado, apoyar a aquellos que beneficiasen sus intereses, y por el otro, poner en duda a quienes iban contra los mismos.

De esta forma, hacia la revolución, la población rural contaba con un "sentido práctico electoral" que la dotó de una aptitud para moverse y actuar siendo razonables frente a los cambios que la soberanía popular traía, orientando sus estrategias según sus necesidades e intereses. Estas eran diferentes según miremos a las autoridades, los distintos sectores de la notabilidad pueblerina, los vecinos de cada pago como el resto de los paisanos. ${ }^{103}$ Todos ellos al estar inmersos en relaciones de poder, desarrollaron estrategias propias tendientes a maximizar su capacidad de negociación. Como la soberanía popular provocó un cambio en la relación de fuerzas entre estos sectores ya que permitía una mayor participación al extender la base electoral, nuevos mecanismos como la capacidad de movilización, el liderazgo, el control de las autoridades sobre la población y los contactos con autoridades superiores, entre otros, fueron puestos en juego en la lucha político-electoral modificando los anteriores. Así, el habitus electoral construido durante la

\footnotetext{
${ }^{101}$ Sobre la participación de alcaldes y curas en los procesos electorales ver GALIMBERTI, Vicente "Autoridades locales y elecciones en la frontera norte bonaerense (1815-1828)", en BARRIERA, Darío y FRADKIN, Raúl (eds.) Gobierno..., cit., pp. 299-327.

102 Para las zonas leales a la Regencia y donde se aplicó la Constitución de Cádiz ver autores citados en la introducción. Para las zonas insurrectas, además del caso que presentamos, en Tucumán y la Banda Oriental se han encontrado situaciones similares a las descriptas. Ver VALLEJO, Gabriela Antiguo..., cit., pp. 219-52 y 328-40; y FREGA, Ana Pueblos y soberanía en la revolución artiguista, Ed. Banda Oriental, Montevideo, 2007, pp. 206-8, 229 y 231-40.

${ }^{103}$ En este sentido seguimos a Florencia Mallon cuando sostiene que aunque no todos los humanos tengan la misma posibilidad (al no tener acceso a las mismas cantidades de poder y de conocimiento, es decir, de construir la historia y el discurso sobre ella), en definitiva, todos participan en la lucha por el poder y por el significado de forma múltiple, aunque en diverso grado. Por lo tanto, en cada ocasión en que los sectores subalternos intervinieron en conflictos por el poder y por el significado, contribuyeron a definir los contornos de lo que era o no posible en la construcción de los ordenamientos políticos. MALLON, Florencia Campesino y Nación. La construcción de México y Perú poscoloniales, Historias, México, 2003.
} 
colonia, nos ayuda a explicar las formas que adoptaron los comportamientos de los actores para afrontar las modificaciones del juego político. Estas, a su vez, enriquecieron y transformaron a aquel dotándolo de nuevos significados a partir de las acciones desarrolladas en cada momento.

Frente a nuevos escenarios, nuevos papeles y libretos eran necesarios. Sin embargo, no había tiempo para ensayos (nunca lo hay en la realidad histórica). El ensayo mismo era la función de gala, por lo tanto las pruebas, aciertos y errores no podían ser modificados de antemano sino tan solo brindar experiencia para el futuro. Las elecciones comentadas muestran las formas en que un grupo social con una herencia cultural, mecanismos mentales, formas de pensar y accionar anteriores, se enfrentó a las teorías y mecanismos electorales basados en la soberanía popular. Por ello, varias de las prácticas desarrolladas remiten a las anteriores, lo cual no resulta para nada extraño dado que usualmente los humanos tienden a procesar las novedades en esquemas mentales previos y conocidos, dotándolos de nuevos significados, transformando aquellas prácticas "viejas" en algo presente, en algo vivo que está en constante cambio. 